\title{
Review of Seawater Intrusion in Western Coastal Regions of South Korea
}

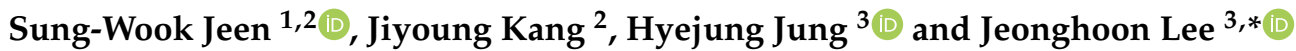 \\ 1 Department of Earth and Environmental Sciences \& The Earth and Environmental Science System Research \\ Center, Jeonbuk National University, Jeonju-si 54896, Korea; sjeen@jbnu.ac.kr \\ 2 Department of Environment and Energy, Jeonbuk National University, Jeonju-si 54896, Korea; \\ kjh51199@naver.com \\ 3 Department of Science Education, Ewha Womans University, Seoul 03760, Korea; hyejeong.chung@gmail.com \\ * Correspondence: jeonghoon.d.lee@gmail.com; Tel.: +82-2-3277-3794
}

check for

updates

Citation: Jeen, S.-W.; Kang, J.; Jung, H.; Lee, J. Review of Seawater Intrusion in Western Coastal Regions of South Korea. Water 2021, 13, 761. https://doi.org/10.3390/w13060761

Academic Editor: Eyal Shalev

Received: 30 January 2021

Accepted: 6 March 2021

Published: 11 March 2021

Publisher's Note: MDPI stays neutral with regard to jurisdictional claims in published maps and institutional affiliations.

Copyright: (c) 2021 by the authors. Licensee MDPI, Basel, Switzerland. This article is an open access article distributed under the terms and conditions of the Creative Commons Attribution (CC BY) license (https:// creativecommons.org/licenses/by/ $4.0 /)$.

\begin{abstract}
Groundwater salinization in coastal aquifers because of seawater intrusion has raised serious concerns worldwide since it deteriorates the quality of drinking water and thereby threatens sustainable economic development. In particular, this problem has been a cause of growing concern in the western coastal regions of South Korea. In this paper, we review studies of seawater intrusion in western coastal regions of South Korea conducted over the past 20 years, particularly focusing on studies reported in international journals. We summarize the study locations, methods used, and major findings from individual and regional-scale studies. General methods used to identify and interpret seawater intrusion and subsequent geochemical processes are also presented. On the basis of insights gleaned from the previous studies, future research needs are discussed.
\end{abstract}

Keywords: seawater intrusion; saline water; groundwater; western coastal region; South Korea; mixing ratio

\section{Introduction}

In many regions of the world, coastal aquifers play an important role in supplying water for domestic and industrial use, since many cities and towns are located close to coastlines. In coastal aquifers, the interface between fresh groundwater and seawater is naturally in equilibrium, balancing oceanic and terrestrial hydrological systems. However, recent studies have provided evidence of this natural equilibrium being disturbed by several factors, causing the freshwater-seawater interface to move inland, a phenomenon termed "seawater intrusion" [1,2]. This phenomenon results in groundwater salinization, which is characterized by increased concentrations of major groundwater constituents, such as $\mathrm{Na}, \mathrm{Mg}, \mathrm{Cl}$, and $\mathrm{SO}_{4}$, and high values of electrical conductivity (EC) or total dissolved solids (TDS) [3-9]. Thus, the phenomenon degrades the quality of groundwater and is therefore of significant concern in many regions.

There are two main reasons for seawater intrusion: natural and anthropogenic processes. It is generally accepted that sea levels will rise in the future because of climate changes. This natural process, which may also be influenced by human activities, will affect the equilibrium between oceanic and terrestrial hydrological systems, causing the freshwater-seawater interface to shift inland [10-13]. Anthropogenically, with the demand for groundwater continuously increasing in many coastal regions because of their economic development, overexploitation of groundwater in coastal aquifers can also induce seawater intrusion [14-18]. Unless coastal aquifers are recharged with freshwater through increased precipitation or artificially, the inland advance of the freshwater-seawater interface may irreversibly affect the quality of groundwater in the aquifers.

Seawater intrusion is a worldwide problem, and it has been reported in virtually all continents, including Asia [19-21], Africa [22,23], Europe [24,25], America [26,27], and 
Oceania [28-30]. In particular, East Asian countries affected by seawater intrusion include Japan and China. In an alluvial coastal aquifer in the Shiroishi lowland plain, Kyushu Island, Japan, intensive extraction of groundwater caused seawater intrusion and land subsidence [31]. Yamanaka et al. [32] investigated the origin of salinity in an aquifer in the Nobi plain in central Japan and determined the geochemical reactions occurring at the freshwater-seawater interface. Huang et al. [33] studied the groundwater chemistry in the coastal area of Dogguan, China, to determine the effects of anthropogenic and natural processes, including seawater intrusion. Han et al. [34] examined seawater intrusion in the coastal aquifer of Laizhou Bay, China, which has complex groundwater dynamics and seawater intrusion resulting from groundwater overexploitation. Liu et al. [35] investigated a sandy aquifer in Ting Kok, Hong Kong, and estimated the extent of the freshwaterseawater interface on the basis of a hydrogeochemical analysis.

In South Korea, seawater intrusion has been an issue on Jeju Island and in coastal regions of mainland South Korea (Table 1 and Figure 1; [36-88]). Early studies on seawater intrusion in South Korea focused on the volcanic Jeju Island [89-97]. The primary source of drinking water on this island is groundwater [41,56], and therefore, groundwater management has been a very important issue on the island. With the rapid growth of the economy of this island, the island has witnessed significant development, particularly in terms of leisure facilities and agriculture. Exploitation of groundwater near coastal areas have caused seawater intrusion, particularly in the eastern parts of the island $[49,80,81,83]$. While studies on the groundwater on Jeju Island are considerably important in this regard, the general application of the study results to other regions of mainland South Korea is limited because the island has a unique geological feature: it mainly comprises basaltic lava flows and a smaller amount of pyroclastics and sedimentary rocks [41,49].

Table 1. Summary of studies on seawater intrusion in South Korea published in international journals.

\begin{tabular}{|c|c|c|c|c|}
\hline Year & Study Site & Study Methods & Major Findings & Reference \\
\hline 1998 & $\begin{array}{l}\text { Wido Island and Byeonsan } \\
\text { Peninsula, Jeollabuk-do * }\end{array}$ & $\begin{array}{l}\text { Analysis of } \\
\text { groundwater } \\
\text { geochemistry; } \\
\text { mixing ratio calculation } \\
\text { using } \mathrm{Cl}^{-}, \mathrm{I}^{-} \text {, and } \mathrm{Br}^{-}\end{array}$ & $\begin{array}{l}\text { Changes in major cation concentrations } \\
\text { resulted from mixing and an ion } \\
\text { exchange reaction; } \\
\text { mixing ratio of seawater was up to } 10 \%\end{array}$ & Kim and Park [36] \\
\hline 2001 & $\begin{array}{l}\text { Hwasung-gun, } \\
\text { Gyeonggi-do * }\end{array}$ & $\begin{array}{l}\text { Groundwater level } \\
\text { measurement; } \\
\text { analysis of } \\
\text { groundwater } \\
\text { geochemistry; } \\
\text { analyses of isotopes } \\
\text { (oxygen and hydrogen); } \\
\text { factor analysis }\end{array}$ & $\begin{array}{l}\text { The groundwater flow system was nearly } \\
\text { in a steady-state condition; } \\
\text { groundwater geochemistry was affected } \\
\text { by seawater intrusion and agricultural } \\
\text { activities, along with cation exchange and } \\
\text { redox reactions }\end{array}$ & Jeen et al. [37] \\
\hline 2002 & $\begin{array}{l}\text { Namyang reclamation } \\
\text { site, Gyeonggi-do * }\end{array}$ & $\begin{array}{l}\text { Electromagnetic } \\
\text { sounding; } \\
\text { chemical analysis of top } \\
\text { soils and groundwater }\end{array}$ & $\begin{array}{l}\text { Seawater intrusion occurred as a channel } \\
\text { and extended to a depth of } 30 \mathrm{~m} \text { from the } \\
\text { sea level; } \\
\text { the region having high concentrations of } \\
\text { major elements was consistent with a } \\
\text { weakly consolidated zone close to the } \\
\text { ground surface }\end{array}$ & Lee et al. [38] \\
\hline 2003 & Kimje, Jeollabuk-do * & $\begin{array}{l}\text { Analyses of major } \\
\text { groundwater chemistry } \\
\text { and oxygen, hydrogen, } \\
\text { and carbon isotopes; } \\
\text { core logging }\end{array}$ & $\begin{array}{l}\text { The hydrogeochemical characteristics of } \\
\text { groundwater were affected by seawater } \\
\text { intrusion, fertilizers, and redox processes; } \\
\text { the tidal changes significantly affected the } \\
\text { groundwater quality }\end{array}$ & Kim et al. [39] \\
\hline
\end{tabular}


Table 1. Cont.

\begin{tabular}{|c|c|c|c|c|}
\hline Year & Study Site & Study Methods & Major Findings & Reference \\
\hline 2003 & Kimje, Jeollabuk-do * & $\begin{array}{l}\text { Chemical analysis } \\
\text { (major cations and } \\
\text { anions, total organic } \\
\text { carbon, and oxygen, } \\
\text { hydrogen, and carbon } \\
\text { isotopes); } \\
\text { cluster analysis }\end{array}$ & $\begin{array}{l}\text { One of the groundwater groups was } \\
\text { mostly affected by chemical fertilizers, } \\
\text { while the other three groundwater groups } \\
\text { were strongly influenced by recent } \\
\text { seawater and trapped ancient seawater }\end{array}$ & Kim et al. [40] \\
\hline 2003 & Jeju Island & $\begin{array}{l}\text { Geochemical and } \\
\text { isotopic }(\mathrm{O}, \mathrm{H}, \mathrm{S} \text {, and } \\
\text { Sr) analyses }\end{array}$ & $\begin{array}{l}\text { Changes in groundwater composition } \\
\text { were largely determined by salinization } \\
\text { and cation exchange processes. }\end{array}$ & Kim et al. [41] \\
\hline 2003 & $\begin{array}{l}\text { Underground liquefied } \\
\text { petroleum gas (LPG) } \\
\text { cavern site, Yeosu, } \\
\text { Jeollanam-do }\end{array}$ & $\begin{array}{l}\text { Chemical analysis; } \\
\text { cross-correlation } \\
\text { analysis }\end{array}$ & $\begin{array}{l}\text { Seawater intrusion caused high } \\
\text { concentrations of cations and anions in } \\
\text { the LPG cavern seepage waters } \\
\text { and groundwaters }\end{array}$ & Lee et al. [42] \\
\hline 2004 & $\begin{array}{l}\text { Yeonggwang-gun, } \\
\text { Jeollanam-do * }\end{array}$ & $\begin{array}{l}\text { Drilling and } \\
\text { geophysical well } \\
\text { logging; } \\
\text { electrical sounding; } \\
\text { numerical modeling }\end{array}$ & $\begin{array}{l}\text { The freshwater-seawater boundary was } \\
\text { determined from the equivalent } \mathrm{NaCl} \\
\text { concentration, which was estimated from } \\
\text { geophysical and hydrogeochemical data }\end{array}$ & Hwang et al. [43] \\
\hline 2004 & Kunsan, Jeollabuk-do * & $\begin{array}{l}\text { Chemical analysis; } \\
\text { stoichiometric analysis }\end{array}$ & $\begin{array}{l}\text { Mineral weathering, anthropogenic } \\
\text { activities, and chloride inputs, such as } \\
\text { seawater and deicer, were important } \\
\text { contributors to groundwater chemistry }\end{array}$ & Kim et al. [44] \\
\hline 2005 & Kimje, Jeollabuk-do * & $\begin{array}{l}\text { Cluster analysis; } \\
\text { factor analysis }\end{array}$ & $\begin{array}{l}\text { The dominant factor affecting } \\
\text { groundwater quality changed from } \\
\text { chemical fertilizers to microbial activity, } \\
\text { and then to seawater intrusion, as } \\
\text { groundwater flowed toward the } \\
\text { coastal area }\end{array}$ & Kim et al. [45] \\
\hline
\end{tabular}

physicochemical

2005 Kimie, Jeollabuk-do * properties of groundwater; correlation analysis

Hydrogeochemical survey;

2005

Western coastal region of South Korea * multivariate statistical analyses log-probability plots;

The groundwater quality was primarily governed by the tidal level, and the

Hydrogeochemical analysis; analysis of total organic carbon and oxygen, hydrogen, and carbon isotopes; core logging

Time series analysis with rainfall, tidal Jeju Island fluctuation, and groundwater level data; geophysical logging and flowmeter analysis strength of the tidal effect was consistent with the tidal period

A "seawater mixing index (SMI)" based on the concentrations of $\mathrm{Na}, \mathrm{Mg}, \mathrm{Cl}$, and $\mathrm{SO}_{4}$ was proposed;

at least around $5 \%$ of groundwaters were affected by seawater mixing
Groundwater salinization was caused by saltwater intrusion, residual salts, and reduction of organic matter in

Kim et al. [48] the sediments

The freshwater-seawater interface was located 6 to $8 \mathrm{~km}$ away from the coastline, and the extent of the interface was related Kim et al. [49]
Kim et al. [46]

Park et al. [47] to the geological features 
Table 1. Cont.

\begin{tabular}{|c|c|c|c|c|}
\hline Year & Study Site & Study Methods & Major Findings & Reference \\
\hline 2007 & Jeju Island & $\begin{array}{l}\text { Mathematical } \\
\text { calculations for } \\
\text { determining the depth } \\
\text { of freshwater-seawater } \\
\text { interface from } \\
\text { pressure data }\end{array}$ & $\begin{array}{l}\text { Methodology to determine the depth of } \\
\text { freshwater-seawater interface from } \\
\text { pressure data obtained from a single } \\
\text { borehole was proposed; } \\
\text { the estimated depth of the } \\
\text { freshwater-seawater interface agreed well } \\
\text { with that determined from the measured } \\
\text { electrical conductivity (EC) profile }\end{array}$ & Kim et al. [50] \\
\hline 2007 & $\begin{array}{l}\text { Underground LPG cavern } \\
\text { site, Pyeongtaek, } \\
\text { Gyeonggi-do * }\end{array}$ & $\begin{array}{l}\text { Cross-correlation } \\
\text { analysis; } \\
\text { principal component } \\
\text { analysis (PCA) }\end{array}$ & $\begin{array}{l}\text { Three hydrogeochemical factors, namely } \\
\text { encrusted cement dissolution, host rock } \\
\text { dissolution, and seawater intrusion, } \\
\text { dominantly affected the } \\
\text { groundwater quality; } \\
\text { groundwater salinization was } \\
\text { characterized on the basis of the } \\
\text { concentration of dissolved ions such as } \mathrm{Br}\end{array}$ & Lee et al. [51] \\
\hline
\end{tabular}
concentration of dissolved ions such as $\mathrm{Br}$

\begin{tabular}{|c|c|c|c|c|}
\hline 2007 & $\begin{array}{l}\text { Western * and southern } \\
\text { coastal regions of South } \\
\text { Korea (Seawater Intrusion } \\
\text { Monitoring Network) }\end{array}$ & $\begin{array}{l}\text { Monitoring of water } \\
\text { levels and } \\
\text { water quality }\end{array}$ & $\begin{array}{l}\text { Groundwater salinization was strongly } \\
\text { related to the withdrawal of groundwater; } \\
\text { a high percentage of the groundwaters } \\
\text { were categorized as } \\
\mathrm{Na}-\mathrm{Cl} \text { and } \mathrm{Ca}-\mathrm{Cl} \text { types, and the } \mathrm{Na}-\mathrm{Cl} \\
\text { type showed the influence of } \\
\text { seawater intrusion }\end{array}$ & Lee and Song [52] \\
\hline 2007 & Buan-gun, Jeollabuk-do * & $\begin{array}{l}\text { Groundwater } \\
\text { chemistry and ionic } \\
\text { ratios; } \\
\text { cross-correlation and } \\
\text { cluster analysis }\end{array}$ & $\begin{array}{l}\text { The groundwaters influenced by seawater } \\
\text { intrusion showed high } \mathrm{Cl} \text { concentration } \\
\text { and high total dissolved solids (TDS); } \\
\text { Groundwater salinization was because of } \\
\text { seawater mixing and cation exchange }\end{array}$ & Lee and Song [53] \\
\hline 2007 & Buan-gun, Jeollabuk-do * & $\begin{array}{l}\text { Vertical electrical } \\
\text { sounding (VES); } \\
\text { core drilling; } \\
\text { chemical analysis } \\
\text { of groundwater }\end{array}$ & $\begin{array}{l}\text { Seawater intrusion was indicated by low } \\
\text { electrical resistivity and ionic ratios; } \\
\text { VES is a useful tool to identify } \\
\text { seawater intrusion }\end{array}$ & Song et al. [54] \\
\hline 2008 & $\begin{array}{l}\text { Western * and southern } \\
\text { coastal regions of South } \\
\text { Korea (Seawater Intrusion } \\
\text { Monitoring Network) }\end{array}$ & $\begin{array}{l}\text { Basic statistics of } \\
\text { groundwater data; } \\
\text { correlation analysis and } \\
\text { trend analyses (Sen's } \\
\text { test and } \\
\text { Mann-Kendall test) }\end{array}$ & $\begin{array}{l}\text { Groundwater levels were largely } \\
\text { influenced by extraction of groundwater } \\
\text { for irrigation and tidal fluctuation; } \\
\text { advance of seawater was indicated by the } \\
\text { vertical EC profile }\end{array}$ & Lee et al. [55] \\
\hline 2008 & Jeju Island & $\begin{array}{l}\text { Monitoring of EC and } \\
\text { temperature with } \\
\text { depth; } \\
\text { cross-correlation } \\
\text { analysis; } \\
\text { end-member } \\
\text { mixing analysis }\end{array}$ & $\begin{array}{l}\text { While a sharp freshwater-seawater } \\
\text { interface was observed at low tide, the } \\
\text { diffusion zone extended to } 20 \mathrm{~m} \text { at } \\
\text { high tide }\end{array}$ & Kim et al. [56] \\
\hline 2009 & Jeju Island & $\begin{array}{l}\text { Groundwater level } \\
\text { measurement; } \\
\text { multidepth EC and } \\
\text { temperature } \\
\text { monitoring }\end{array}$ & $\begin{array}{l}\text { The multidepth monitoring system was } \\
\text { helpful for evaluating } \\
\text { freshwater-seawater interaction }\end{array}$ & Kim et al. [57] \\
\hline
\end{tabular}


Table 1. Cont.

\begin{tabular}{|c|c|c|c|c|}
\hline Year & Study Site & Study Methods & Major Findings & Reference \\
\hline 2012 & Okgye, Gangwon-do & $\begin{array}{l}\text { Major ion chemistry; } \\
\text { analysis of oxygen and } \\
\text { hydrogen isotopes; } \\
\text { reaction path modeling }\end{array}$ & $\begin{array}{l}\text { The main sources of salinity were } \\
\text { rainwater impacted by sea-salt spray for } \\
\text { the upstream aquifer and seawater } \\
\text { intrusion for the downstream } \\
\text { coastal aquifer }\end{array}$ & Chae et al. [58] \\
\hline 2012 & $\begin{array}{c}\text { Masan, } \\
\text { Gyeongsangnam-do }\end{array}$ & $\begin{array}{l}\text { Hydrogeochemical } \\
\text { analyses; } \\
\text { chemometrics (cluster } \\
\text { analysis, factor analysis, } \\
\text { and discriminant } \\
\text { analysis) and kriging }\end{array}$ & $\begin{array}{l}\text { Combined use of chemometrics and } \\
\text { kriging was helpful for identifying } \\
\text { sources of groundwater contamination, } \\
\text { which included seawater intrusion }\end{array}$ & Kim et al. [59] \\
\hline 2012 & $\begin{array}{l}\text { Western * and southern } \\
\text { coastal regions of South } \\
\text { Korea (Seawater Intrusion } \\
\text { Monitoring Network) }\end{array}$ & $\begin{array}{l}\text { Basic statistics; } \\
\text { trend analysis and } \\
\text { correlation analysis; } \\
\text { conductivity profiling }\end{array}$ & $\begin{array}{l}\text { Groundwater levels in South Korea can be } \\
\text { affected by rainfall and sea level changes, } \\
\text { which are associated with climate changes } \\
\text { and potentially cause increased } \\
\text { seawater intrusion }\end{array}$ & $\begin{array}{c}\text { Song and } \\
\text { Zemansky [60] }\end{array}$ \\
\hline 2012 & $\begin{array}{l}\text { Eastern, western *, and } \\
\text { southern coastal regions of } \\
\text { South Korea (Seawater } \\
\text { Intrusion } \\
\text { Monitoring Network) }\end{array}$ & $\begin{array}{l}\text { Automatic monitoring } \\
\text { of water level, EC, and } \\
\text { temperature; } \\
\text { periodic } \\
\text { chemical analysis }\end{array}$ & $\begin{array}{l}\text { Based on the threshold values of } \mathrm{Cl}^{-} \text {and } \\
\mathrm{Br}^{-}, 41-50 \% \text { of the groundwaters were } \\
\text { impacted by mixing with seawater }\end{array}$ & Park et al. [61] \\
\hline 2012 & Muan, Jeollanam-do * & $\begin{array}{l}\text { Time series analysis } \\
\text { (EC, groundwater level, } \\
\text { and tidal oscillation); } \\
\text { hydraulic tests }\end{array}$ & $\begin{array}{l}\text { The extent of seawater intrusion was } \\
\text { highly dependent on hydrogeologic } \\
\text { features such as hydraulic connectivity; } \\
\text { continuous withdrawal of groundwater } \\
\text { could exacerbate seawater intrusion in the } \\
\text { coastal fractured aquifer }\end{array}$ & Park et al. [62] \\
\hline 2013 & $\begin{array}{l}\text { Yeonggwang-gun, } \\
\text { Jeollanam-do * }\end{array}$ & $\begin{array}{l}\text { Monitoring of } \\
\text { groundwater level and } \\
\text { TDS; } \\
\text { groundwater analysis } \\
\text { model (FEMWATER) }\end{array}$ & $\begin{array}{l}\text { Inland movement of the } \\
\text { freshwater-seawater boundary can be } \\
\text { reduced by artificially recharging aquifers } \\
\text { with freshwater }\end{array}$ & Jun and Jang [63] \\
\hline 2013 & Jeju Island & $\begin{array}{l}\text { Numerical simulation } \\
\text { with } \\
\text { sensitivity analysis }\end{array}$ & $\begin{array}{l}\text { The horizontal length and vertical depth } \\
\text { of highly permeable layers are important } \\
\text { factors for inland seawater intrusion }\end{array}$ & Kim et al. [64] \\
\hline 2013 & $\begin{array}{l}\text { Underground LPG cavern } \\
\text { site, Yeosu, Jeollanam-do }\end{array}$ & $\begin{array}{l}\text { Geochemical and } \\
\text { isotopic analyses; } \\
\text { PCA }\end{array}$ & $\begin{array}{l}\text { The chemistry of the cavern seepage } \\
\text { water was primarily influenced by } \\
\text { seawater mixing and dissolution of } \\
\text { cement material; } \\
\text { the estimated seawater mixing ratio in the } \\
\text { seepage water ranged from less than } 1 \% \\
\text { to } 14 \%\end{array}$ & Lim et al. [65] \\
\hline 2014 & Yangyang, Gangwon-do & $\begin{array}{l}\text { Sediment coring; } \\
\text { chemical and isotopic } \\
\left(\delta^{34} \mathrm{~S} \text { and }\right. \\
\left.\delta^{18} \mathrm{O}\right) \text { analyses }\end{array}$ & $\begin{array}{l}\text { The coastal aquifer was affected by } \\
\text { seawater intrusion, apart from being } \\
\text { characterized by } \\
\text { sulfate-reducing conditions }\end{array}$ & Kim et al. [66] \\
\hline
\end{tabular}


Table 1. Cont.

\begin{tabular}{|c|c|c|c|c|}
\hline Year & Study Site & Study Methods & Major Findings & Reference \\
\hline 2014 & $\begin{array}{l}\text { Saemangeum reclaimed } \\
\text { area, Jeollabuk-do * }\end{array}$ & $\begin{array}{l}\text { Chemical and isotopic } \\
\left(\delta^{18} \mathrm{O} \text { and } \delta^{2} \mathrm{H}\right) \\
\text { analyses; } \\
\text { electrical resistivity } \\
\text { survey; } \\
\text { pumping test and } \\
\text { automatic monitoring } \\
\text { of groundwater level } \\
\text { and EC }\end{array}$ & $\begin{array}{l}\text { The transition zone between freshwater } \\
\text { and seawater ranged from } 30 \text { to } 50 \mathrm{~m} \\
\text { below the ground surface; } \\
\text { the seawater content of groundwater was } \\
\text { higher in the reclaimed land compared } \\
\text { with inland. }\end{array}$ & Lee et al. [67] \\
\hline 2015 & $\begin{array}{l}\text { Suyeong district, } \\
\text { Busan city }\end{array}$ & $\begin{array}{l}\text { Water chemistry; } \\
\text { use of water quality } \\
\text { index (WQI) }\end{array}$ & $\begin{array}{l}\text { The groundwater composition was } \\
\text { primarily determined by three dominant } \\
\text { factors: weathering, seawater intrusion, } \\
\text { and sewer leakage }\end{array}$ & Chung et al. [68] \\
\hline 2015 & $\begin{array}{l}\text { Suyeong district, } \\
\text { Busan city }\end{array}$ & $\begin{array}{l}\text { Water chemistry; } \\
\text { geographic information } \\
\text { system (GIS)-based } \\
\text { spatial mapping; } \\
\text { correlation and } \\
\text { cluster analyses }\end{array}$ & $\begin{array}{l}\text { Seawater intrusion, salinized river water, } \\
\text { leaked sewers, and groundwater } \\
\text { discharge from a subway dominantly } \\
\text { affected the groundwater quality }\end{array}$ & $\begin{array}{l}\text { Venkatramanan } \\
\text { et al. [69] }\end{array}$ \\
\hline 2015 & $\begin{array}{l}\text { Underground LPG cavern } \\
\text { site, Yeosu, Jeollanam-do }\end{array}$ & $\begin{array}{l}\text { Field monitoring of } \\
\text { groundwater levels and } \\
\text { water chemistry; } \\
\text { numerical modeling }\end{array}$ & $\begin{array}{l}\text { Modeled seawater mixing ratios of the } \\
\text { cavern seepage waters ranged from } 0.01 \% \\
\text { to } 8.70 \% \text {, while the measured mixing } \\
\text { ratios based on } \mathrm{Cl} \text { - concentrations ranged } \\
\text { from } 2.3 \% \text { to } 12.8 \%\end{array}$ & Lee et al. [70] \\
\hline 2015 & Jeju Island & $\begin{array}{l}\text { Physicochemical } \\
\text { parameter analysis; } \\
\text { next generation } \\
\text { sequencing } \\
\text { (NGS)-based microbial } \\
\text { community analysis }\end{array}$ & $\begin{array}{l}\text { Groundwater samples with high salinity } \\
\text { shared } 6.7 \% \text { of bacterial species with } \\
\text { seawater, while the other groundwater } \\
\text { samples shared less than } 0.5 \% \text {. }\end{array}$ & Unno et al. [71] \\
\hline 2017 & Jeju Island & $\begin{array}{l}\text { Chemistry analyses; } \\
\text { microbial community } \\
\text { statistical analyses; } \\
\text { groundwater level } \\
\text { monitoring; } \\
\text { numerical simulation }\end{array}$ & $\begin{array}{l}\text { Submarine groundwater discharge rate is } \\
\text { a vital factor that affects the dynamics of } \\
\text { the microbial community structure in } \\
\text { coastal areas }\end{array}$ & Lee et al. [72] \\
\hline 2017 & $\begin{array}{l}\text { Samrak Park Delta, } \\
\text { Busan city }\end{array}$ & $\begin{array}{l}\text { Geochemical analyses } \\
\text { of sediments and } \\
\text { groundwater; } \\
\text { multivariate statistical } \\
\text { analysis; } \\
\text { multilayer perceptron } \\
\text { artificial neural } \\
\text { network (ANN) model }\end{array}$ & $\begin{array}{l}\text { The chemical constituents of sediments } \\
\text { and groundwater were mostly derived } \\
\text { from source rocks and seawater intrusion }\end{array}$ & $\begin{array}{l}\text { Venkatramanan } \\
\text { et al. [73] }\end{array}$ \\
\hline 2017 & $\begin{array}{l}\text { Yeonjegu district, } \\
\text { Busan city }\end{array}$ & $\begin{array}{l}\text { Hydrogeochemical } \\
\text { analyses; } \\
\text { statistical analysis; } \\
\text { fuzzy GIS techniques }\end{array}$ & $\begin{array}{l}\text { The major ion chemistry was mainly } \\
\text { related to natural processes, while } \\
\text { seawater intrusion and municipal } \\
\text { contaminants were secondary sources of } \\
\text { groundwater contamination }\end{array}$ & $\begin{array}{l}\text { Venkatramanan } \\
\text { et al. [74] }\end{array}$ \\
\hline 2018 & Nam-gu district, Busan city & $\begin{array}{l}\text { Time series analysis } \\
\text { using EC, water } \\
\text { pressure, precipitation, } \\
\text { and tide data }\end{array}$ & $\begin{array}{l}\text { Inland seawater intrusion had progressed } \\
\text { significantly during the nine-year } \\
\text { investigation period and it had } \\
\text { significantly affected the } \\
\text { groundwater quality }\end{array}$ & Chung et al. [75] \\
\hline
\end{tabular}


Table 1. Cont

\begin{tabular}{|c|c|c|c|c|}
\hline Year & Study Site & Study Methods & Major Findings & Reference \\
\hline 2018 & $\begin{array}{l}\text { Geological repository for } \\
\text { low and intermediate } \\
\text { radioactive waste (LILRW), } \\
\text { southeastern coastal area of } \\
\text { South Korea }\end{array}$ & $\begin{array}{l}\text { Monitoring of } \\
\text { groundwater level and } \\
\text { hydrogeochemistry }\end{array}$ & $\begin{array}{l}\text { During the construction of the geological } \\
\text { repository for LILRW, the groundwater } \\
\text { level decreased below the sea level, } \\
\text { resulting in an increase in EC in several } \\
\text { wells near the coast; } \\
\text { the groundwater salinity was mainly } \\
\text { because of seawater intrusion, with an } \\
\text { important contribution from ion exchange }\end{array}$ & Kim et al. [76] \\
\hline 2018 & $\begin{array}{l}\text { Western coastal area of } \\
\text { South Korea (Taean-gun, } \\
\text { Chungcheongnam-do)* }\end{array}$ & $\begin{array}{l}\text { Multicriteria } \\
\text { decision-making } \\
\text { methods; } \\
\text { numerical modeling } \\
\text { (SEAWAT) }\end{array}$ & $\begin{array}{l}\text { Taean-gun, Chungcheongnam-do, was } \\
\text { found to be the most susceptible to } \\
\text { seawater intrusion among } 25 \text { areas over } \\
\text { the western coastal regions of } \\
\text { South Korea; } \\
\text { Taean-myeon in Taean-gun was } \\
\text { determined to be a priority area for } \\
\text { application of countermeasures against } \\
\text { seawater intrusion }\end{array}$ & Kim and Yang [77] \\
\hline
\end{tabular}

\begin{tabular}{|c|c|c|c|c|}
\hline 2019 & $\begin{array}{c}\text { Seocheon, } \\
\text { Chungcheongnam-do * }\end{array}$ & $\begin{array}{l}\text { "Interface-Egg"; } \\
\text { pumping tests; } \\
\text { monitoring of } \\
\text { groundwater level } \\
\text { and EC }\end{array}$ & $\begin{array}{l}\text { A freshwater-seawater interface tracking } \\
\text { device ("Interface-Egg") can be useful for } \\
\text { evaluating temporal changes in } \\
\text { the interface }\end{array}$ & Kim et al. [78] \\
\hline 2019 & $\begin{array}{l}\text { Yeonggwang-gun, } \\
\text { Jeollanam-do * }\end{array}$ & $\begin{array}{l}\text { Elemental and isotope } \\
\text { analyses; } \\
\text { cluster analysis }\end{array}$ & $\begin{array}{l}\text { The complex hydrogeochemical } \\
\text { characteristics of the groundwater system } \\
\text { resulted from the reclamation process, } \\
\text { land use, old seawater intrusion, and } \\
\text { reduction processes }\end{array}$ & Kim et al. [79] \\
\hline 2019 & Jeju Island & $\begin{array}{l}\text { Index-based seawater } \\
\text { intrusion vulnerability } \\
\text { model (GALDIT) }\end{array}$ & $\begin{array}{l}\text { The vulnerability of southwestern areas of } \\
\text { Jeju Island to seawater intrusion is } \\
\text { increasing because of the decreasing } \\
\text { groundwater level }\end{array}$ & Chang et al. [80] \\
\hline 2020 & Jeju Island & $\begin{array}{l}\text { Monitoring of } \\
\text { groundwater level and } \\
\text { multidepth salinity; } \\
\text { numerical modeling } \\
\text { (SEAWAT and } \\
\text { GALDIT) }\end{array}$ & $\begin{array}{l}\text { While the current use of groundwater } \\
\text { from the coastal aquifer of Jeju Island may } \\
\text { not cause seawater intrusion, seawater } \\
\text { intrusion could occur if the dry conditions } \\
\text { persist in the future }\end{array}$ & Chang et al. [81] \\
\hline 2020 & Jeju Island & $\begin{array}{l}\text { Chemical analysis; } \\
\text { statistical analysis: } \\
\text { thermodynamic } \\
\text { modeling }\end{array}$ & $\begin{array}{l}\text { Seawater intrusion in the southeastern } \\
\text { area was attributed to the distribution of } \\
\text { Seogwipo Formation. However, this } \\
\text { formation prevents intrusion in other } \\
\text { areas by acting as an aquiclude }\end{array}$ & Lee et al. [82] \\
\hline 2020 & Jeju Island & $\begin{array}{l}\text { Geophysical well } \\
\text { logging; } \\
\text { borehole temperature } \\
\text { monitoring }\end{array}$ & $\begin{array}{l}\text { Seawater intrusion occurred through } \\
\text { multilayered aquifers, which act as a } \\
\text { flow pathway }\end{array}$ & $\begin{array}{c}\text { Shin and Hwang } \\
\text { [83] }\end{array}$ \\
\hline 2020 & $\begin{array}{l}\text { Geological repository for } \\
\text { LILRW, southeastern } \\
\text { coastal area of South Korea }\end{array}$ & $\begin{array}{l}\text { Geochemical analysis; } \\
\text { isotopic }\left(\delta \mathrm{D}, \delta^{18} \mathrm{O} \text {, and }\right. \\
\left.\delta^{34} \mathrm{~S}_{\mathrm{SO} 4}\right) \text { analysis }\end{array}$ & $\begin{array}{l}\text { Seawater intrusion in the fractured coastal } \\
\text { aquifer resulted from groundwater } \\
\text { discharge during the construction of the } \\
\text { underground LILRW repository; } \\
\text { seawater intrusion and accompanying } \\
\text { hydrogeochemical reactions varied } \\
\text { considerably over time and space }\end{array}$ & Kwon et al. [84] \\
\hline
\end{tabular}


Table 1. Cont.

\begin{tabular}{|c|c|c|c|c|}
\hline Year & Study Site & Study Methods & Major Findings & Reference \\
\hline 2020 & $\begin{array}{l}\text { Ninety-one reclaimed land } \\
\text { areas in western * and } \\
\text { southern coastal regions of } \\
\text { South Korea, with detailed } \\
\text { analysis of Heungwang } \\
\text { (Gyeonggi-do)* and } \\
\text { Deokchon (Jeollanam-do) } \\
\text { reclaimed lands }\end{array}$ & $\begin{array}{l}\text { Composite model for } \\
\text { seawater intrusion and } \\
\text { soil salinization with } \\
\text { sea level rise scenarios }\end{array}$ & $\begin{array}{l}\text { Groundwater salinization can be } \\
\text { accelerated in the } 91 \text { reclaimed land areas } \\
\text { by seawater intrusion because of sea } \\
\text { level rise; } \\
\text { small watersheds can have further inland } \\
\text { penetration of seawater, while ponds with } \\
\text { water levels higher than sea level can } \\
\text { prevent seawater intrusion }\end{array}$ & Jung et al. [85] \\
\hline 2020 & $\begin{array}{l}\text { Gyeongin-Ara Waterway, } \\
\text { Gyeonggi-do * }\end{array}$ & $\begin{array}{l}\text { Analytic hierarchy } \\
\text { process (AHP) model; } \\
\text { artificial neural } \\
\text { network (ANN) model }\end{array}$ & $\begin{array}{l}\text { Seawater intrusion is occurring near the } \\
\text { Gyeongin-Ara Waterway and is in } \\
\text { progress in surrounding aquifers }\end{array}$ & Kim [86] \\
\hline 2020 & $\begin{array}{l}\text { Archipelago in the } \\
\text { southwestern sea, } \\
\text { Jeollanam-do * }\end{array}$ & $\begin{array}{l}\text { Chemical analysis; } \\
\text { PCA; } \\
\text { ionic delta by mixing } \\
\text { ratio }\end{array}$ & $\begin{array}{l}\mathrm{Ca}-\mathrm{Cl} \text { and } \mathrm{Na}-\mathrm{Cl} \text { types of groundwater } \\
\text { were contaminated with seawater and } \\
\text { accounted for } 91.9 \% \text { of the total samples; } \\
\text { seawater mixing ratios were calculated to } \\
\text { be } 0-10.4 \% \text { and } 0-7.6 \% \text { on the basis of } \mathrm{Cl} \\
\text { and } \mathrm{Br} \text { ions, respectively }\end{array}$ & Shin et al. [87] \\
\hline 2021 & Hwaseong-si, Gyeonggi-do * & $\begin{array}{l}\text { Monitoring of } \\
\text { groundwater level and } \\
\text { hydrogeochemistry; } \\
\text { age-dating using }{ }^{3} \mathrm{H} \text {, } \\
\text { tritiogenic }{ }^{3} \mathrm{He} \text {, } \\
\text { radiogenic }{ }^{4} \mathrm{He} \text {, } \\
\mathrm{CFC}-11, \mathrm{CFC}-12 \text {, } \\
\text { and CFC-113 }\end{array}$ & $\begin{array}{l}\text { Density-driven upward flow occurs at the } \\
\text { interface of seawater intrusion, which } \\
\text { forces old groundwater to flow into the } \\
\text { shallow aquifer }\end{array}$ & Ju et al. [88] \\
\hline
\end{tabular}

* Study on western coastal regions.

On the other hand, western coastal regions of South Korea have recently attracted interest for seawater intrusion studies. The western coastline generally forms a "ria"-type coast, which has a highly irregular and indented coastline, and it is characterized by a macrotidal regime, with a tidal range of up to $6 \mathrm{~m}$. Thus, there is high potential of seawater intrusion in these regions [47]. Most of the papers related to seawater intrusion in these regions have been published after 2000 (Table 1), indicating that interest in groundwater resources in these regions is recent. In view of future research needs in these regions, such as studies on the impact of geological storage sites on groundwater quality $[42,51,65,70,76,84]$, it is expected that groundwater salinization resulting from seawater intrusion could receive more attention in the near future. However, to date, there has been no review study to summarize the lessons learned from seawater intrusion studies in the western coastal regions of South Korea.

In this review paper, we overview the learnings from studies on seawater intrusion in the western coastal regions of South Korea conducted over the past 20 years. We summarize the features and results of the studies, including the study locations, methods used, and major findings from individual and regional-scale studies. The scope of our review is mainly confined to papers published in international journals, except for a few early studies, to ensure that it is of interest to international researchers. We also present the general methods used for the identification and interpretation of seawater intrusion, including freshwater and seawater mixing ratio calculations, and elucidate the accompanying geochemical processes. On the basis of the implications of the results of the past studies, future research needs are discussed. 


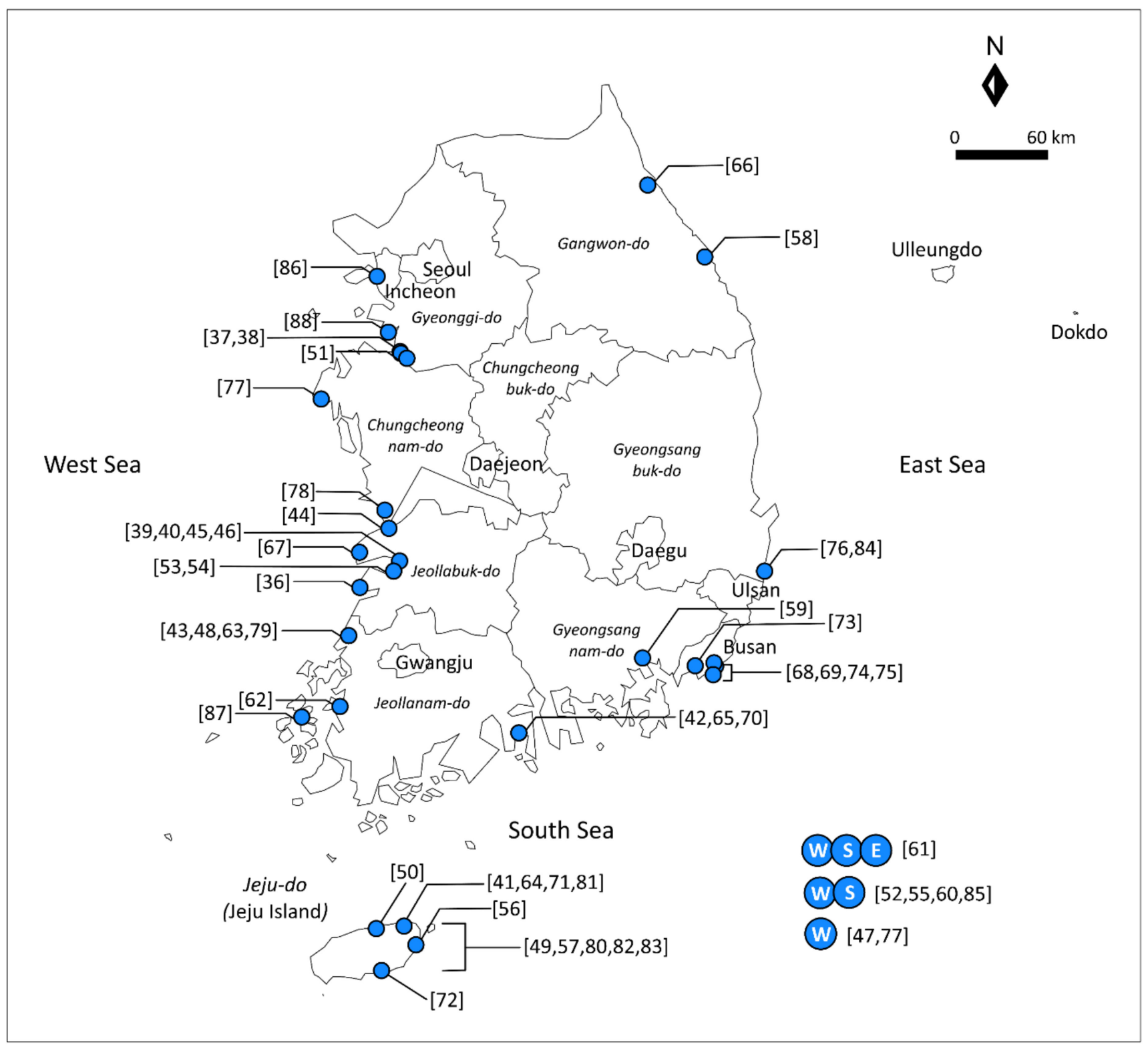

Figure 1. Locations of the seawater intrusion study sites in South Korea (W: western coastal region; S: southern coastal region; and E: eastern coastal region).

\section{Methods and Basic Scientific Approaches for Seawater Intrusion Studies}

The major scientific questions on seawater intrusion can be summarized as follows:

(1) How can we characterize seawater's influence on groundwater?

(2) To what extent does groundwater mix with seawater?

(3) What are the hydrogeochemical processes that occur during seawater mixing?

The methods and basic approaches proposed for addressing these questions are discussed in this section.

\subsection{Identification of Seawater Intrusion}

Different approaches can be used in studies of seawater intrusion in coastal aquifers, such as hydrogeochemical methods (including analyses of major ions and isotopes), statistical analysis, and numerical modeling $[26,28]$. On the other hand, in zones where monitoring wells are scarce or absent, the application of geophysical methods can provide valuable information at a reasonable cost compared with the high cost of drilling new wells 
and installing piezometers for collecting groundwater samples for chemical analysis [25]. Electrical and electromagnetic techniques have been extensively used in hydrogeological investigations because of the relationship between the electrical (and hydraulic) properties of geological formations and the saturation of fluid contained in geological materials [98]. Three complementary geophysical methods, namely, gravity, vertical electrical sounding, and frequency domain electromagnetic methods, have been used in combination with hydrogeological and hydrogeochemical investigations for defining the characteristics of aquifers and assessing the extension of the seawater intrusion [25].

The basic statistics of the chemical composition of groundwater, especially in situ measurements (e.g., EC, TDS, $\mathrm{pH}$, and temperature), have been widely used to identify the amount of seawater mixed with fresh groundwater. EC (greater than $1 \mathrm{mS} / \mathrm{cm}$ ) or TDS can be used as an indication of the mixing of saline water with fresh groundwater. High temporal and spatial dispersions of the standard deviation, which may indicate variability in the hydrochemical composition of groundwater samples (temporal) and between samples (spatial), can indicate the presence of polluting sources. High standard deviations of $\mathrm{Na}^{+}$and $\mathrm{Cl}^{-}$indicate that the groundwater in the study area may be affected by various factors, such as seawater intrusion and silicate weathering [87]. The ion ratios between different chemical species are frequently used to evaluate seawater intrusion in coastal areas [87]. For example, the value of $\mathrm{r}\left(\mathrm{Cl}^{-} / \mathrm{HCO}_{3}{ }^{-}\right)$has been referred to as an effective index for determining the extent of seawater mixing. A value less than 0.5 indicates that there is no effect of seawater, a value between 0.5 and 1.3 implies a slight effect, a value between 1.3 and 2.8 reflects a moderate one, a value between 2.8 and 6.6 indicates a severe effect, and a value of 6.6 or more can be interpreted as the seawater effect is very severe. The dissolved ion analysis of groundwater samples can be shown in a trilinear diagram, called a Piper diagram (Figure 2), in which water samples are classified into four types. This representation can be successfully used for evaluating a limited number of groundwater samples. However, a problem arises when the analysis requires identification of relationships between the chemical and physical parameters and their temporal variations because the tri-linear diagram is based on the ratio of the chemical compositions.

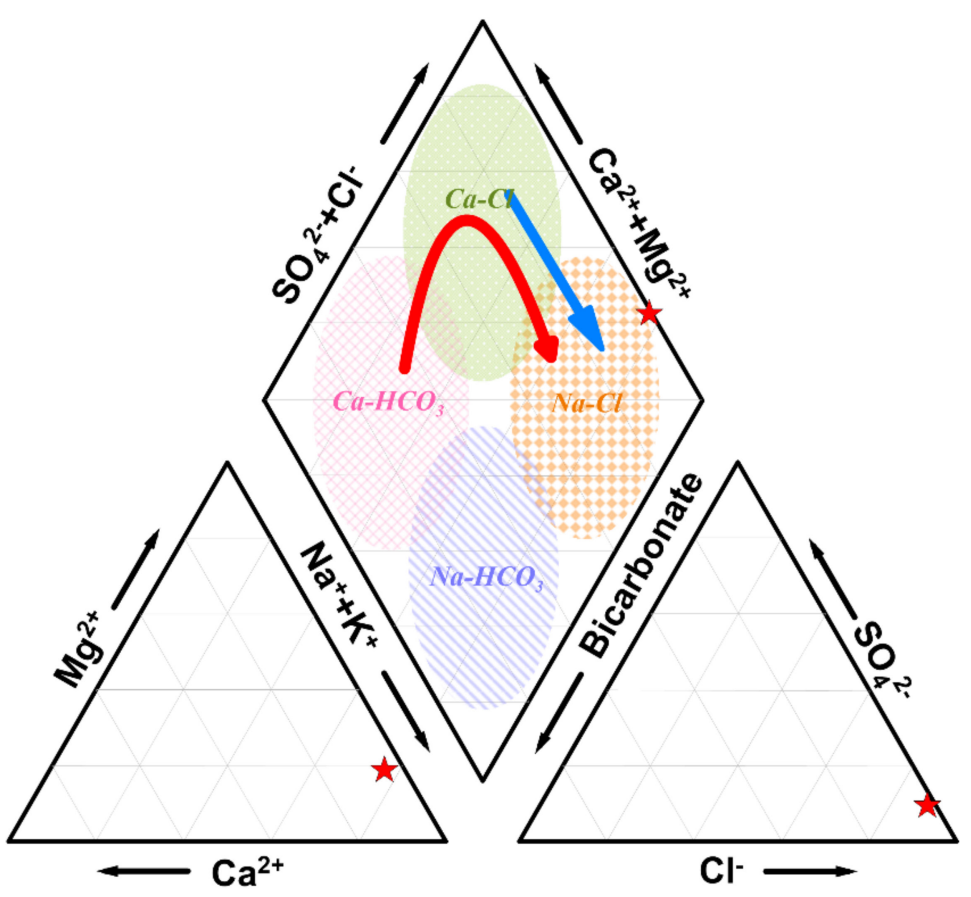

Figure 2. Piper diagram representing the mixing of groundwater and seawater. A red star represents the chemical composition of seawater. The mixing between seawater and $\mathrm{Ca}-\mathrm{HCO}_{3}$ is indicated by the red arrow and the mixing between seawater and Ca-Cl-type water is indicated by the blue arrow. 
Multivariate statistical analysis, such as principal component analysis (PCA), has been used to identify the influence of seawater on groundwater. PCA reduces the information in many chemical variables into a set of weighted linear combinations of those variables, and it does not differentiate between common and unique variance [99-101]. Because PCA is based entirely on eigenvalue analysis of a correlation or covariance matrix, the data is not required to be normally distributed. Normally, PCA is applied to the correlation matrix because the chemical variables vary by different orders of magnitude. The summarized information in the PCA plot is used for finding relationships, patterns, and waters with extreme chemical compositions and for further statistical modeling [102,103].

Proper management of seawater intrusion issues requires good knowledge of aquifer systems and the ability to predict their future behavior under different scenarios of naturally forcing and anthropogenic interactions [104]. In this respect, numerical simulation is widely used to examine seawater intrusion in coastal aquifers and to evaluate alternative groundwater-resource-management scenarios [105]. Seawater intrusion is physically a density-dependent problem, where two different equations should be implicitly coupled. Among the available modeling approaches, variable-density groundwater flow models that track seawater movement can be classified into interface models and dispersive solute transport models [104]. Early modeling studies replaced the disperse transition zone representing the freshwater-seawater interface with a sharp front and introduced other simplifications, such as quasi three-dimensional layered aquifers or the Dupuit assumption of predominantly horizontal flow [106]. In dispersive solute transport models, such as SUTRA, FEFLOW, and SEAWAT, the fluid density can vary continuously or from cell to cell in a model domain [63]. Among the dispersive solute transport models, SUTRA and FEFLOW solve the flow and transport equations simultaneously, while SEAWAT has the option to solve the transport equation separately using particle-based or finite difference methods and compute a new flow field to represent a changing density field [104]. Seawater intrusion can be evaluated through the detailed geological reconstruction of coastal zones; this constitutes the core phase of the construction of a robust hydrogeological conceptual and numerical model. All other possible processes, such as sea level changes, changes in temperature and precipitation, coastline erosion, and land subsidence, should be considered in future simulations of seawater intrusion.

\subsection{Mixing Calculations}

Mixing ratios $(x)$ based on conservative tracers, which have been widely used to determine the mixing of freshwater and seawater, can be obtained from the law of mass conservation as follows:

$$
x=\frac{C_{\text {sample }}-C_{\text {freshwater }}}{C_{\text {seawater }}-C_{\text {freshwater }}}
$$

where $C_{\text {freshwater }}, C_{\text {seawater }}$, and $C_{\text {sample }}$ are the concentrations or isotopic ratios of freshwater, seawater, and the groundwater sample. While the determination of the chemical and isotopic compositions of end members for performing mixing analysis, namely, the end member mixing analysis (EMMA), is difficult in other hydrogeochemical studies, the selection of end members and the chemical and isotopic compositions of the chosen end members is relatively nonproblematic in seawater intrusion studies. The lowest value of the analyzed groundwater data in a study area can be used in EMMA by employing conservative tracers. We summarize the chloride and bromide concentrations used in previous studies (Table 2). Past studies have reported mixing ratios between fresh groundwater and seawater calculated using Equation (1). For example, Shin et al. [87] quantitatively calculated the influence of seawater on groundwater and found it to range from 0 to 7.6 (on the basis of $\mathrm{Cl}^{-}$ions) and 0 to 10.4 (on the basis of $\mathrm{Br}^{-}$ions). 
Park et al. [47] suggested a seawater mixing index (SMI) based on the concentrations of the four major ion components in seawater, namely $\mathrm{Na}^{+}, \mathrm{Cl}^{-}, \mathrm{Mg}^{2+}$, and $\mathrm{SO}_{4}{ }^{2-}$ :

$$
S M I=0.31 \times \frac{C_{N a}}{T_{N a}}+0.04 \times \frac{C_{M g}}{T_{M g}}+0.57 \times \frac{C_{C l}}{T_{C l}}+0.08 \times \frac{C_{S_{4}}}{T_{S O_{4}}}
$$

where $C$ is the measured concentration $(\mathrm{mg} / \mathrm{L})$ and $T$ is the regional threshold value, which can be calculated from the interpretation of the cumulative probability function. If the SMI is greater than 1, the groundwater can be significantly influenced by seawater. Park et al. [47] proved the effectiveness of the SMI; they found that samples with an SMI greater than 1 were located within $4 \mathrm{~km}$ from the western coastline.

Table 2. Chloride and bromide concentrations of seawater or brackish water reported in previous studies.

\begin{tabular}{|c|c|c|c|c|}
\hline Year & Study Site & $\mathrm{Cl}^{-}(\mathrm{mg} / \mathrm{L})$ & $\mathrm{Br}^{-}(\mathrm{mg} / \mathrm{L})$ & Reference \\
\hline 1997 & Yeosu, South Korea & $14,230.5 \pm 528.2$ & NA & Kim et al. [107] \\
\hline 2001 & $\begin{array}{l}\text { Mid-western coast, } \\
\text { South Korea }\end{array}$ & $19,300.0$ & 73.0 & Jeen et al. [37] \\
\hline 2002 & Gogum, South Korea & $17,164.0$ & NA & Shin et al. [108] \\
\hline 2003 & Jeju, South Korea & $18,211.0$ & 64.7 & Kim et al. [41] \\
\hline 2004 & Castell de Ferro, Spain & $21,259.0$ & 132.0 & Pulido-Leboeuf [109] \\
\hline 2005 & $\begin{array}{l}\text { Western coastal area, } \\
\text { South Korea }\end{array}$ & $19,350.0$ & NA & Park et al. [47] \\
\hline 2005 & $\begin{array}{l}\text { Seomjin River, } \\
\text { South Korea }\end{array}$ & $18,800.0$ & 67.0 & Na and Son [110] \\
\hline 2005 & Sicily, Italy & $21,204.5 \pm 34.7$ & NA & Capaccioni et al. [111] \\
\hline 2005 & Saloum, Senegal & $19,888.7 \pm 2423.4$ & 67.0 & Faye et al. [112] \\
\hline 2006 & $\begin{array}{c}\text { Yeonggwang, South } \\
\text { Korea }\end{array}$ & $14,408.0$ & 67.0 & Kim et al. [48] \\
\hline 2007 & Buan, South Korea & $16,716.0$ & NA & Lee and Song [53] \\
\hline 2009 & $\begin{array}{l}\text { Sacheon and Hadong, } \\
\text { South Korea }\end{array}$ & 2846.0 & NA & Kim et al. [113] \\
\hline 2015 & Daweijia, China & $16,211.5 \pm 668.1$ & NA & Han et al. [114] \\
\hline 2017 & $\begin{array}{c}\text { Marbella-Estepona, } \\
\text { Spain }\end{array}$ & $19,472.0$ & 66.0 & Argamasilla et al. [115] \\
\hline 2020 & Shinan, South Korea & 1554.7 & 5.2 & Shin et al. [87] \\
\hline 2020 & $\begin{array}{l}\text { Hwaseong-si, } \\
\text { South Korea }\end{array}$ & 1107.7 & NA & Ju et al. [88] \\
\hline
\end{tabular}

NA: Not analyzed.

\subsection{Ionic Delta by Mixing Ratio}

The ionic delta $(\Delta)$ has been utilized as an important indicator of the hydrogeochemical reactions between solid and liquid phases in coastal aquifers $[35,47]$. It denotes the difference between the measured and theoretical concentrations of ion $i$ when fresh groundwater and seawater are mixed conservatively:

$$
\Delta C_{i}=C_{i, \text { sample }}-C_{i, m i x}
$$

where $\Delta C_{i}$ is the ionic delta of ion $i, C_{i, \text { sample }}$ is the measured concentration of $i$ in the sample, and $C_{i, m i x}$ is the theoretical concentration of $i$ in the conservative mixture of fresh groundwater and seawater. The theoretical concentration is calculated by considering the seawater concentration $\left(f_{\text {sea }}\right)$ obtained from the conservative tracer concentration in the sample. For example, given the bromide concentration $\left(C_{B r \text { sample }}\right)$, the $\mathrm{Br}^{-}$concentration 
in the fresh groundwater $\left(C_{B r, f g}\right)$, and the $\mathrm{Br}^{-}$concentration of the seawater $\left(C_{B r, s e a}\right), f_{\text {sea }}$ is given by

$$
f_{\text {sea }}=\frac{\left(C_{B r, \text { sample }}-C_{B r, f g}\right)}{\left(C_{B r, \text { sea }}-C_{B r, f g}\right)}
$$

In this way, the seawater concentration of each sample can be calculated, which is the same as the previous calculation method for the mixing ratio using $\mathrm{Br}$ ions (Equation (4)). This seawater concentration is then used to calculate the theoretical concentration of each ion:

$$
C_{i, m i x}=f_{\text {sea }} C_{i, \text { sea }}+\left(1-f_{\text {sea }}\right) C_{i, f g}
$$

These calculations consider the fact that $\mathrm{Br}^{-}$is a conservative tracer. Notably, $\mathrm{Br}^{-}$is not usually removed from the system because of its high solubility. The only sources of $\mathrm{Br}^{-}$are the aquifer matrix salts and a salinization source, such as seawater intrusion.

\subsection{Understanding the Geochemical Processes Involved in Groundwater-Seawater Mixing}

Cation exchange reactions are the one of the most important hydrogeochemical reactions in the soil and aquifers and govern the change of matter, migration, and weathering of minerals $[1,3,4]$. They are as follows:

$$
\begin{gathered}
2 \mathrm{Na}^{+}+\mathrm{Ca}-\mathrm{X}_{2} \rightarrow 2 \mathrm{Na}-\mathrm{X}+\mathrm{Ca}^{2+} \\
2 \mathrm{Na}^{+}+\mathrm{Mg}-\mathrm{X}_{2} \rightarrow 2 \mathrm{Na}-\mathrm{X}+\mathrm{Mg}^{2+}
\end{gathered}
$$

Here, $\mathrm{X}$ is a soil ion exchanger. When groundwater and seawater mix in an aquifer, an ion exchange reaction occurs between $\mathrm{Ca}^{2+}, \mathrm{Mg}^{2+}$, and $\mathrm{Na}^{+}$until the $\mathrm{Na}^{+}$concentration of the seawater-intruded groundwater saturates because of the seawater. Overall, all the ionic deltas are positive $\left(\Delta \mathrm{Na}^{+}+\Delta \mathrm{K}^{+}>0, \Delta \mathrm{Mg}^{2+}>0\right.$, and $\left.\Delta \mathrm{Ca}^{2+}>0\right)$, which cannot simply be attributed to ion exchange. Positive ionic deltas were also observed in a sandy aquifer in the coastal area of Zealand, Denmark, and it could be explained by the external input of $\mathrm{Ca}^{2+}$ by the dissolution of calcite minerals in the aquifer [35]. However, calcite precipitation cannot be observed if the aquifers consist mostly of weathered granite, being unsaturated with respect to calcium ions.

The relationship between the seawater mixing ratio $(X)$ and the ionic delta $(Y)$ value of each ion is shown in Figure 3. In the case of $\Delta \mathrm{Ca}^{2+}$, it increased with the mixing ratio, while $\Delta \mathrm{Na}^{+}$showed a tendency to decrease with an increase in the mixing ratio. Since $\mathrm{Na}^{+}$ and $\mathrm{Ca}^{2+}$ participated in a cation exchange reaction, the $\mathrm{Na}$ ions were adsorbed by the ion exchangers and $\mathrm{Ca}^{2+}$ was released. Hence, as the seawater mixing ratio increased, $\Delta \mathrm{Ca}^{2+}$ increased and $\Delta \mathrm{Na}^{+}$decreased.

Figure 4 presents the relationship between $\Delta \mathrm{Ca}^{2+}$ and $\Delta \mathrm{Mg}^{2+}$ versus $\Delta \mathrm{Na}^{+}+\Delta \mathrm{K}^{+}$. The data located in the second and fourth quadrants (the blue area) explain the cation exchange process. In the second quadrant, $\mathrm{Mg}^{2+}$ or $\mathrm{Ca}^{2+}$ is exchanged by $\mathrm{Na}^{+}$or $\mathrm{K}^{+}$, while in the fourth quadrant, the reverse process occurs. In the first and third quadrants, the external sources (dissolution) or sinks (precipitation) play an important role in controlling the concentrations of ions in the groundwater. In the first quadrant, the input of ions would induce the exchange of this input ion with other cations adhered on the surface of the sediment and subsequently release the ions into the groundwater, resulting in the positive ionic delta $(\Delta)$ values for all cations. The third quadrant describes the net removal of ions from the groundwater, for example, through precipitation of minerals in the aquifer. For instance, if $\mathrm{Mg}^{2+}$ or $\mathrm{Ca}^{2+}$ precipitates as dolomite or calcite, respectively, then $\mathrm{Mg}^{2+} \mathrm{or} \mathrm{Ca}^{2+}$ in the groundwater decreases. To compensate the solution, $\mathrm{Mg}^{2+}$ or $\mathrm{Ca}^{2+}$ on the sediment exchanger will desorb into the groundwater. 


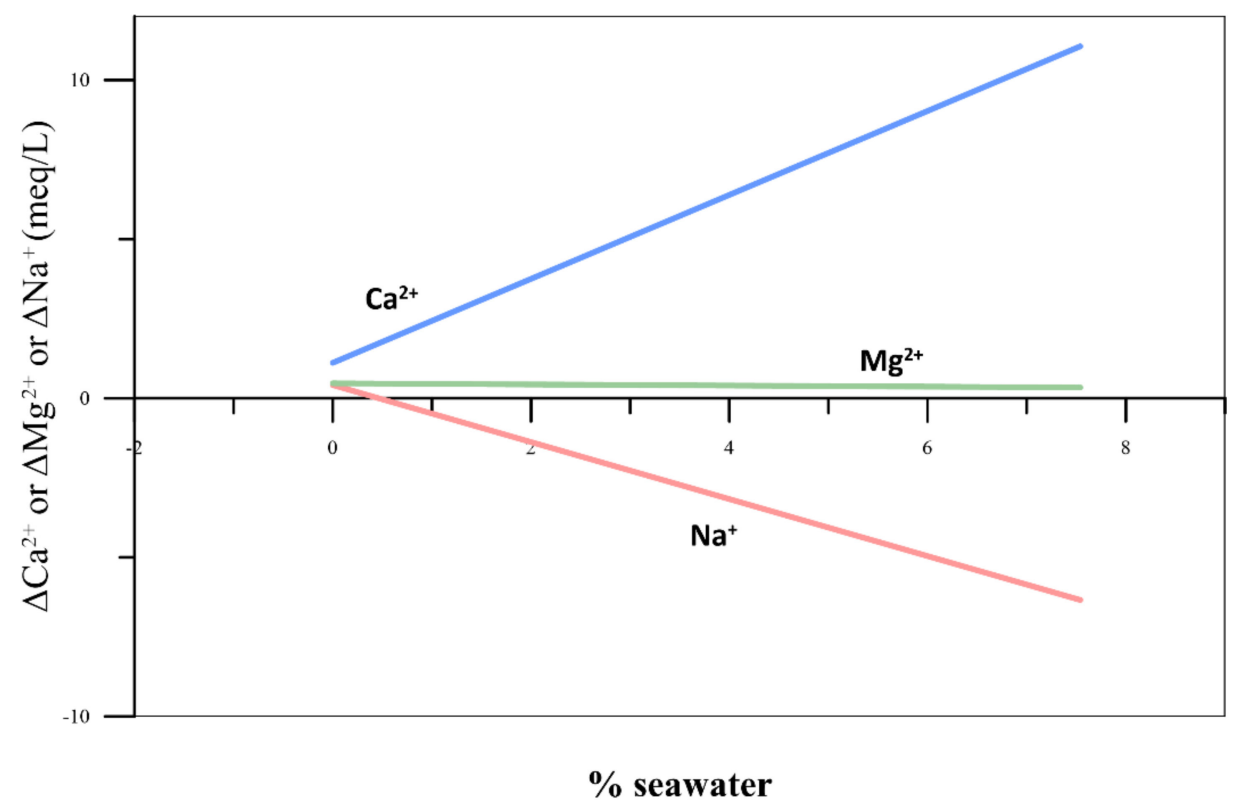

Figure 3. Plots of $\Delta \mathrm{Ca}^{2+}, \Delta \mathrm{Mg}^{2+}$, and $\Delta \mathrm{Na}^{+}$vs. the percentage of seawater equal to the mixing ratio using conservative ions.

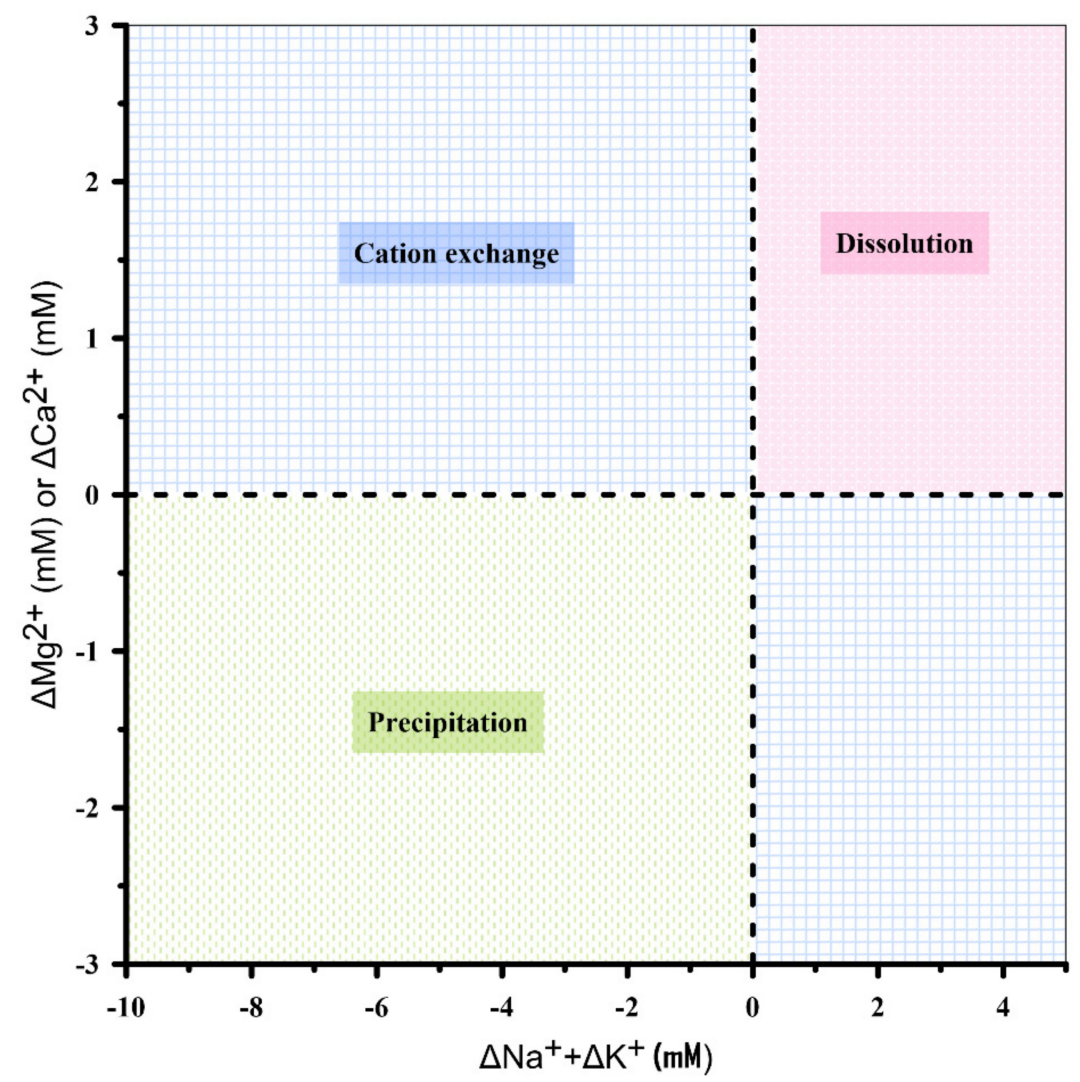

Figure 4. Plot of $\Delta \mathrm{Mg}^{2+}$ or $\Delta \mathrm{Ca}^{2+}$ vs. $\Delta \mathrm{Na}^{+}+\Delta \mathrm{K}^{+}$, showing the mechanism by which major cations participate in coastal groundwater mixing.

\section{Seawater Intrusion in South Korea}

3.1. Overview of Seawater Intrusion Studies in South Korea

Before 2000, groundwater studies related to seawater intrusion in South Korea focused on Jeju Island and most papers were published in domestic journals. As mentioned, groundwater is the principal source of drinking water in Jeju Island $[41,56,116]$, and 
therefore, groundwater studies have been important for this island. The residence time of groundwater on Jeju Island has been studied by using environmental tracers since the late 1960s [117,118]. Studies on seawater intrusion on Jeju Island commenced way back in 1986 [89]. Youn [89] investigated the salinity of groundwater throughout Jeju Island and found that groundwaters in the eastern part of the island had a higher salinity content than those in the western and central areas and that the eastern area was more susceptible to seawater intrusion. Since then, several studies have been conducted to investigate seawater intrusion into coastal aquifers on the island [90-97], and groundwater overexploitation has been suggested to be the main cause of seawater intrusion [91-93]. After 2000, diverse aspects of seawater intrusion, including geophysical monitoring, numerical modeling, and microbial investigation, have been studied on Jeju Island (Table 1). However, the results of studies on this island may not be directly applicable to other coastal regions of mainland South Korea since the island has a unique hydrogeological setting [39,41,49].

\subsection{Seawater Intrusion Studies over Western Coastal Regions of South Korea}

In mainland South Korea, western coastal regions are known to be more prone to seawater intrusion compared with southern and eastern coastal regions because of their topographic characteristics and excessive use of groundwater for agricultural irrigation. The western regions form topographically flat discharge zones with respect to the nationalscale hydrogeological flow regime, and the groundwater levels are typically a few meters below the land surface [47]. The geologic strata comprising aquifers are moderately to highly permeable, and hence, they are vulnerable to seawater intrusion [47]. Heavy groundwater pumping for agricultural irrigation has also contributed to serious seawater intrusion problems in these regions. The resulting high salinity has adversely affected crop yield in some areas [55]. Furthermore, the ocean tide has a significant influence on the seawater intrusion [87]. Most papers related to seawater intrusion in the western coastal regions appeared after 2000. Table 1 summarizes seawater intrusion studies in South Korea published in international journals, including those pertaining to Jeju Island and other coastal regions of mainland South Korea. Figure 1 shows the location of each study site. In this section, we briefly summarize the results of studies pertaining to the western coastal regions of mainland South Korea. The studies are categorized on the basis of the methodologies employed in them.

\subsubsection{Hydrogeochemical Analyses}

Owing to significant differences in the chemical compositions of groundwater and seawater, hydrogeochemical analyses have been the most common and fundamental method used for investigations of seawater intrusion. Hydrogeochemical analyses have involved graphical representation of water chemistry, seawater mixing ratio calculations using compositions of major ions and isotopes, and stoichiometric analysis.

One of the early studies published in international journals was that of Kim and Park [36], who evaluated the hydrogeochemical characteristics of groundwater and seawater on Wido Island and Byeonsan Peninsula, Jeollabuk-do. The geology of the site consists of andesitic to acidic tuff, granite, and Kyeokpori Formation, which is composed of siliclastic and volcaniclastic sedimentary sequences. The $\mathrm{Ca}^{2+} / \mathrm{Na}^{+}$and $\mathrm{Ca}^{2+} / \mathrm{Mg}^{2+}$ ratios were used to determine the status of the geochemical evolution of the groundwater with respect to seawater intrusion and cation exchange stages. Depending on the degree of seawater intrusion, the groundwater types were shifted from the carbonate hardness type to the noncarbonate hardness type (or ion exchange type) and eventually to the noncarbonated alkali type. The maximum mixing ratio of seawater, calculated using the chloride concentration, was $9.2 \%$.

Kim et al. [44] investigated the groundwater in the coastal area of Kunsan, Jeollabukdo, to identify the contaminant sources and their effects on the groundwater chemistry. The bedrocks of the study area are diorites and granites, which intruded the overlying sedimentary rocks and granitic gneiss and schist. The surface is covered by a thick alluvium 
that is up to $40 \mathrm{~m}$. Owing to the existence of multiple contaminant sources and complex hydrochemical processes, a mass balance analysis based on the stoichiometry of mineral weathering was performed to evaluate the controlling processes. The results of the analysis showed that groundwater chemistry could be explained by mineral dissolution, nitrification and oxidation of organic matter, and chloride inputs (e.g., from seawater, deicer, and $\mathrm{NaCl}$ ). For the chloride-rich group, the groundwater chemistry was considerably affected by seawater intrusion, which was followed by cation exchange reactions. The water chemistry was also shown to be considerably affected by mineral weathering, suggesting that seawater resided in the aquifer for a relatively long time before it affected the groundwater chemistry.

Kim et al. [48] used isotopic compositions (i.e., $\delta \mathrm{D}, \delta^{18} \mathrm{O}$, and $\delta^{13} \mathrm{C}$ ) in addition to concentrations of major cations and anions, iodide, and total organic carbon to examine the groundwater salinization process in the coastal reclaimed area of Yeonggwang-gun, Jeollanam-do. The lithology of the study area consists mainly of Jurassic granite, biotite granite, and Quaternary alluvium. Due to the increased needs for agricultural and residential developments, many coastal areas in South Korea have been reclaimed from the see or muddy beaches, and the coastline used to be more inland than it is now. As a result, the hydrogeochemical properties of groundwaters in the reclaimed areas are expected to be different from those of areas directly impacted by seawater intrusion. On the basis of the hydrogeochemical features of the groundwaters at the study site, it was suggested that the groundwaters were predominantly influenced by three factors: seawater intrusion, fertilizers, and redox processes. It was also shown that land reclamation had caused the burial of a large amount of organic matter and its reduction in the sediments, controlling groundwater salinization in addition to seawater intrusion.

\subsubsection{Statistical Analyses for Interpreting Groundwater Chemistry}

In the western coastal regions of South Korea, industrial and agricultural activities are predominant, and therefore the groundwaters are susceptible to contamination by various sources, not only from salinization resulting from present and old seawater intrusion. In order to differentiate the salinity sources of groundwaters, seawater intrusion studies have successfully employed statistical analyses, including factor analysis, PCA, cluster analysis, and correlation analysis, as tools.

Jeen et al. [37] presented a basic approach for delineating groundwater salinization in a western coastal area. The approach involved combining the groundwater level measurement, interpretation of major chemistry and isotope composition, and statistical analysis. They studied the hydrogeological and hydrogeochemical characteristics of groundwater in Hwasung-gun, Gyeonggi-do. The bedrock of the study area is composed of Pre-Cambrian gneiss and a schist complex, which is overlaid with Quaternary alluvium. Their investigation conducted in both the dry and rainy seasons showed that the groundwater system was almost in a steady-state, and the pattern of groundwater flow was consistent with the spatial distribution of groundwater components. The groundwater geochemistry was characterized by a high chloride concentration and the cation concentrations deviated from those at a simple freshwater-seawater mixing line because of the cation exchange reactions between the aquifer materials and seawater. Groundwaters were grouped into the $\mathrm{Ca}\left(\mathrm{HCO}_{3}\right)_{2}, \mathrm{CaCl}_{2}$, and $\mathrm{NaCl}$ types, and it was suggested that the $\mathrm{CaCl}_{2}$ type could be used to determine the location of the interface between freshwater and seawater. The isotopic composition and factor analysis indicated that the hydrogeochemical characteristics of groundwater were affected by seawater intrusion and agricultural activities.

Kim et al. [39] examined the temporal and spatial differences in the physicochemical properties of groundwater in Kimje, Jeollabuk-do, to evaluate the main factors affecting the groundwater quality. The bedrock of the study area is Jurassic granite, which is overlaid with Quaternary alluvium. On the basis of its hydrogeochemical characteristics, the groundwater was largely grouped into the $\mathrm{Na}^{+}-\mathrm{Cl}^{-}$and $\mathrm{Ca}^{2+}+\mathrm{Mg}^{2+}-\mathrm{NO}_{3}{ }^{-}+\mathrm{Cl}^{-}$types, which were affected by seawater intrusion, fertilizers, and redox processes. The $\mathrm{Na}^{+}-\mathrm{Cl}^{-}$type of groundwater was shown to be affected by old seawater as well as modern seawater, while 
the $\mathrm{Ca}^{2+}+\mathrm{Mg}^{2+}-\mathrm{NO}_{3}{ }^{-}+\mathrm{Cl}^{-}$type was contaminated by fertilizers. It was also shown that the redox condition changed from oxic to suboxic/anoxic as the groundwater flowed from inland to the coastal area. In a subsequent paper of Kim et al. [40], using cluster analysis, the authors classified groundwater in the study area into four categories, A, B, C, and D. Present and old seawater intrusion was the major factor determining the groundwater quality of groups B, C, and D, while chemical fertilizers were the primary factor influencing the groundwater quality of group A. On the basis of previous studies and using factor analysis, Kim et al. [45] showed that three factors account for $82 \%$ of the total variance of 17 variables, namely, seawater intrusion, microbial activity, and chemical fertilizers. As groundwater flowed from inland (group A) to the coastal area (group D), the main factor controlling the groundwater quality gradually changed from chemical fertilizers to seawater intrusion and microbial activity. Furthermore, Kim et al. [46] applied correlation analysis to evaluate the influence of tide on groundwater quality. The tidal level governed the groundwater quality and the strength of the tidal effect varied with the tidal period. Based on a times series analysis, a conceptual model of seawater intrusion depending on the tidal level was proposed. According to the conceptual model, the freshwater-seawater interface moves inland during the spring tide because the increased tidal level can overcome the hydraulic pressure barrier between the seawater and groundwater. By contrast, during neap tide, the hydraulic pressure gap between the seawater and groundwater is the lowest as the tidal level decreases, and it results in recession of the seawater because of seaward-moving freshwater and hence less saline groundwater.

Underground storage facilities, such as liquefied petroleum gas (LPG) caverns, can act as artificial groundwater sinks. When these facilities are constructed in coastal areas, the hydrogeological and hydrogeochemical characteristics of the aquifer system can be affected by seawater intrusion. Lee et al. [51] investigated the hydrogeological system of an underground LPG cavern constructed in the coastal area of Pyeongtaek, Gyeonggi-do. The oldest rocks of the study area are mainly composed of arkosic sandstone and conglomerate, and most of the surface rocks are composed of andesitic lavas, welded tuffs, and acidic dykes. They interpreted the groundwater flow path by using cross-correlation analysis along with hydraulic properties and assessed the dominant components controlling the groundwater chemistry by using PCA. Three hydrogeochemical components, namely, host rock dissolution, encrusted cement dissolution, and seawater intrusion, were classified from the results of PCA. The freshwater-seawater mixing ratios, calculated from the chloride concentration, were estimated to be $0.3-4.8 \%$ for moderately saline water and $5.0-32.2 \%$ for saline groundwater.

Using cluster analysis, Kim et al. [79] classified groundwaters in the reclaimed coastal area of Yeonggwang-gun, Jeollanam-do, to evaluate the main factors affecting the hydrogeochemical characteristics of the groundwaters. On the basis of the results of the cluster analysis using physicochemical properties, groundwaters were classified into four groups, A, B, C, and D. Groups A and B were found to be affected by old seawater intrusion, on the basis of the correlation between chloride and the major cations/anions. These groups were also shown to be affected by $\mathrm{Mn}$ and Fe reduction. Furthermore, sulfate reduction appeared to occur since the sulfate concentration was significantly low compared with the values estimated from a simple freshwater-seawater mixing model. Additionally, enriched ${ }^{34} \mathrm{~S}_{\mathrm{SO} 4}$ values (30.7-57.3\%) were observed in Groups A and B. It was concluded that the groundwater systems were affected by the reclamation process, land use, old seawater intrusion, and reduction processes.

Shin et al. [87] investigated the influence of seawater on the groundwater quality in an archipelago located in the southwestern sea in Jeollanam-do by using PCA and ionic deltas by mixing ratios. The geology of the study area consists of granite along with gneiss and schist, which is covered by the unconfined clastic sedimentary. The alluvial layer has covered the other strata unconformably. Groundwaters were classified on the basis of the water quality type and $\mathrm{Cl}^{-} / \mathrm{HCO}_{3}{ }^{-}$molar ratio. Two water types, the $\mathrm{Ca}-\mathrm{Cl}$ and $\mathrm{Na}-\mathrm{Cl}$ types, were considered to be affected by seawater and accounted 
for $91.9 \%$ of the total samples. The seawater mixing ratio calculated from the chloride concentration was in the range of $0-10.4 \%$ (average of $1.0 \%$ ), while the mixing ratio based on the bromide concentration was in the range of $0-7.6 \%$ (average of $0.6 \%$ ). In PCA, the first component represented the influence of seawater and explained $54.1 \%$ of the variance, and groundwater samples with large seawater mixing ratios were from the region where this component had significant influence. Ionic delta values were used to identify the cation exchange reaction and groundwater-seawater mixing, and it was found that there was a specific relationship between the ionic delta value of each ion and the mixing ratio during seawater mixing and geochemical reactions.

\subsubsection{Hydrogeological Investigation}

While hydrogeochemical analyses have been used as basic methods to identify the effects of seawater intrusion on groundwater systems, hydrogeological investigations, including identification of saline water pathways or groundwater discharge flow paths, the freshwater-seawater interface, and groundwater age, have also been used to better understand hydrogeological systems in coastal zones.

Park et al. [62] performed a hydrogeological investigation in Muan, Jeollanam-do, to evaluate seawater intrusion in a tidal-forced coastal fractured aquifer, which had been subjected to intense groundwater pumping. The bedrock of the study area is granite gneiss, and the weathered soil is well developed on the surface. A time series analysis performed with the EC, groundwater level, tidal oscillation data, and flowmeter tests showed that seawater intrusion was caused by heavy groundwater pumping from the wells near the coast and that the intrusion was advancing through specific conductive fractures. The conductive fractures became a pathway for the deep saline water flowing up to the transition zone. The extent of the transition zone depended on changes in the groundwater level resulting from groundwater extraction and recharge. It was concluded that continuous heavy groundwater pumping could exacerbate seawater intrusion into the coastal fractured aquifer.

To identify an alternative water resource in the Saemangeum reclaimed area in Jeollabuk-do, Lee et al. [67] investigated coastal groundwater discharge (CGD), which is the subsurface flow from inland to the coast. The bedrock of the study area consists mainly of Jurassic granite, which is overlain by Quaternary alluvium. Cretaceous acidic volcanic rock intrudes the granite. On the basis of an electrical resistivity survey, a weathered-rock layer in the reclaimed land was identified as the main CGD pathway. Furthermore, vertical EC profiling revealed that the transition zone between freshwater and saline water was located $30-50 \mathrm{~m}$ below the surface. The aquifer in the reclaimed land was found to be more influenced by seawater compared with those inland. Using a saline water pumping test, they examined the possibility of water quality improvement if water flow in the CGD were to be enhanced. The results of the pumping test showed a notable enhancement of the water quality (EC decrease of $900-1600 \mu \mathrm{S} \mathrm{cm}^{-1}$ ), suggesting that CGD could be an alternative water resource for the reclaimed land.

Locating the freshwater-seawater interface is important for the management of coastal aquifer systems. Kim et al. [78] tested a freshwater-seawater interface tracking device (called "Interface-Egg") to evaluate temporal changes in the interface during several pumping tests, which were conducted at monitoring wells in Seocheon, Chungcheongnam-do. In the study area, Quaternary alluvium overlies Carboniferous granite, which is underlain by Jurassic sedimentary rock and Precambrian gneiss. The tracking device has a density between those of freshwater and seawater and can therefore move up and down as the freshwater-seawater transition zone changes. During the pumping test, EC profiles showed that seawater upconing in the pumping well occurred rapidly, and the groundwater level recovered very slowly. Furthermore, time series groundwater head data and the location of the tracking device indicated that there was a tidal influence on the groundwater level. It was suggested that the tracking device could be practically used for the management of coastal aquifer systems, particularly for areas with dynamic groundwater extraction. 
Ju et al. [88] used multiple groundwater age tracers, such as ${ }^{3} \mathrm{H}$, tritiogenic ${ }^{3} \mathrm{He}$, radiogenic ${ }^{4} \mathrm{He}, \mathrm{CFC}-11$, CFC-12, and CFC-113, to study a coastal aquifer system in Hwaseong-si, Gyeonggi-do, where groundwater levels had been decreasing because of heavy groundwater utilization, raising concerns about seawater intrusion. The lithology of the study area is composed of Precambrian granite gneiss and Quaternary alluvial deposits. Groundwater age distributions around the seawater intrusion zone were inferred using the multiple tracers and Bayesian inference. The mean groundwater ages were in the range of 10.9 to 522.5 years, and the groundwater ages were not directly related to the regional head gradient, indicating that the aquifer system was not a simple recharge-to-discharge flow system. The estimated groundwater age distributions near the seawater intrusion interface had characteristics of heavy-tailed mixing structures, indicating that old groundwater rich in ${ }^{4} \mathrm{He}$ at the seawater intrusion interface was forced to move upward into the shallow aquifer by density-driven flow. It was concluded that Bayesian inference could provide insights into the flow dynamics at a complex seawater interface.

\subsubsection{Geophysical Monitoring}

Geophysical surveys are an effective tool to understand coastal aquifer systems, and they complement hydrogeochemical and hydrogeological investigations. Lee et al. [38] combined geophysical monitoring techniques, namely the electromagnetic sounding technique and geochemical analysis of soil and groundwater, to detect the seawater-intruded zone in paddy fields near the Namyang reclamation site in Gyeonggi-do. The bedrock of the study area mainly consists of schist and gneiss and the alluvium is deposited under the paddy fields. Vertical electrical sounding (VES) revealed that the seawater intrusion zone was near the surface, and that there was a channel located $30 \mathrm{~m}$ below sea level. Furthermore, geochemical analyses of the top soils showed that a region with high concentrations of the major elements in seawater was consistent with a weakly consolidated zone near the surface, which was vulnerable to seawater intrusion. Statistical analysis showed that the $\mathrm{Na}, \mathrm{Cl}$, and $\mathrm{Mg}$ concentrations in soils could indicate the degree of salinization resulting from seawater intrusion.

Hwang et al. [43] used geophysical well logging and electrical soundings to delineate the spatial distribution of seawater intrusion in a coastal aquifer of Yeonggwang-gun, Jeollanam-do. The geological structure of the survey area consists of mud, sand, and granite bedrock. From the subsurface geology mapped from drilling and VES, they developed a simplified numerical model for groundwater flow and transport. The resistivity and porosity were estimated through geophysical well logging, and they were used to estimate the pore water resistivity of the aquifer. The location of the freshwater-seawater boundary was mapped using the equivalent $\mathrm{NaCl}$ concentration, which was determined from geophysical and hydrogeochemical data.

Lee and Song [53] studied seawater intrusion in Buan-gun, Jeollabuk-do, using groundwater chemistry and ionic ratios, along with cluster analysis. There are generally three hydrogeologic layers in the study site. The uppermost layer is a reclamation soil, which is classified into silty loam or silty clay loam. A weathered layer of sandy loam or loam exists in the middle, followed by the bottom layer, which is a fresh to slightly fractured sedimentary rock. They showed that the major groundwater compositions could be effectively used to ascertain the influence of seawater intrusion. In particular, the $\mathrm{Cl}$ and TDS concentrations and ionic ratios, such as $\mathrm{HCO}_{3} / \mathrm{Cl}, \mathrm{Na} / \mathrm{Ca}, \mathrm{Ca} / \mathrm{Cl}, \mathrm{Mg} / \mathrm{Cl}$, and $\mathrm{Ca} / \mathrm{SO}_{4}$, were found to be useful indicators of seawater intrusion. The results of the cluster analysis were consistent with those of major groundwater chemistry. At the same study site, Song et al. [54] conducted electrical resistivity surveys to map the spatial extent of seawater intrusion, along with core drillings and groundwater chemistry analysis. The VES indicated a highly conductive zone in the middle layer, which was identified as a weathered rock layer from the drilling log data. The conductive zone was mostly distributed near the coastal area, indicating the strong effect of seawater intrusion. Areas with low ionic ratios and high TDS values were consistent with the low-resistivity areas indicated by the VES 
results, suggesting that VES could be a useful tool for mapping coastal areas affected by seawater intrusion.

\subsubsection{Numerical Modeling}

Numerical modeling has been used to identify areas vulnerable to seawater intrusion and to evaluate the effects of countermeasures against seawater intrusion. Jun and Jang [63] used the groundwater analysis model FEMWATER to evaluate the features of seawater intrusion in Yeonggwang-gun, Jeollanam-do, where alluvium lies widely. Using groundwater level data and TDS values from seawater intrusion monitoring wells, they developed a three-dimensional numerical model and performed a simulation to evaluate the role of artificial recharge in reducing the negative impact of seawater intrusion. The simulation results showed that the freshwater-seawater boundary moved inland in spring because of the increase in water demand for the cultivation of arable land. The inland movement of the freshwater-seawater boundary could be efficiently reduced through artificial recharge of freshwater, indicating that such a recharge could be used as a measure to safeguard against damage caused by seawater intrusion.

Kim and Yang [77] proposed a three-step procedure to prioritize areas vulnerable to seawater intrusion. Countermeasures could then be applied to the areas to reduce the effect of seawater intrusion. First, using multicriteria decision-making methods, the area most susceptible to seawater intrusion was selected from among 25 areas in the western coast of South Korea. The area selected was Taean-gun in Chungcheongnam-do. Second, representative concentration pathways (RCPs) 4.5 and 8.5, which were used as sea level rise scenarios, and future groundwater-use scenarios, determined by linear-regression analysis, were used to predict areas of future seawater intrusion by employing a numerical model, SEAWAT. Finally, the effectiveness of countermeasures in reducing seawater intrusion areas was evaluated by considering a projected future scenario and local characteristics. The results showed that Taean-myeon in Taean-gun was the area where seawater intrusion could be prevented most effectively. Countermeasures considered in the simulation were the construction of recharge ponds and limiting the use of groundwater. It was suggested that other alternatives, such as seawater pumping, freshwater injection, and using a low permeable barrier, could also be considered in the future.

Jung et al. [85] assessed the applicability of a composite model for evaluating seawater intrusion in coastal aquifers resulting from climate changes. In their approach, flow in a saturated zone was simulated using a three-dimensional model, and flow in an unsaturated zone was simulated using a vertical one-dimensional model. The RCP 4.5 and 8.5 scenarios were applied to compute the sea level rise for 91 country-managed reclaimed areas in South Korea. Furthermore, two representative reclaimed land areas, the Heungwang (Gyeonggi-do) and Deokchon (Jeollanam-do) reclaimed lands, were selected and seawater intrusion in these two areas were examined in detail. The simulation results showed that sea level rise could cause widespread damage in the 91 reclaimed land areas and groundwater salinization would be accelerated over time because of seawater intrusion. The 91 reclaimed land areas were characterized by the presence of ponds, pond locations, management water levels of the ponds, and the watershed size. It was shown that seawater could penetrate further inland in a small watershed, while ponds with water levels greater than the sea level could efficiently prevent seawater intrusion. The approach of Jung et al. [85] could be used to establish a national-level plan for the management of water resources.

Kim [86] used an analytic hierarchy process (AHP) model to delineate the protection area of Gyeongin-Ara (GA) Waterway in Gyeonggi-do, which consists of riverside alluvial deposits, on the basis of two primary factors and five secondary factors associated with seawater intrusion. Several artificial neural network (ANN) models were developed using the secondary criteria of the AHP model and evaluation score. The final evaluation score calculated by the ANN model was used to select the groundwater protection area, where the evaluation score was greater than 2.0 and accounted for $15 \%$ of the total simulation cells. This area fell within $200 \mathrm{~m}$ of the GA Waterway and encompassed some sites where 
changes in hydrogeochemistry resulting from seawater intrusion were observed. It was concluded that the nonlinear ANN model could be more efficient than the AHP model for making predictions.

\subsubsection{Regional-Scale Studies}

A few regional-scale investigations have been conducted over the western coastal regions of South Korea to obtain general insights into seawater intrusion throughout the western coastline. Park et al. [47] conducted a regional-scale hydrogeochemical survey of shallow groundwaters along almost the entire length of the western coastline of South Korea. The survey showed that the groundwater chemistry was governed by several interrelated processes, such as seawater mixing, water-rock interaction, and anthropogenic contamination. On the basis of cumulative probability curves for the concentrations of chloride and nitrate, groundwaters were classified into four types, and about $5 \%$ of the groundwater samples were shown to be significantly influenced by seawater mixing. They proposed an SMI on the basis of the concentrations of $\mathrm{Na}, \mathrm{Mg}, \mathrm{Cl}$, and $\mathrm{SO}_{4}$, and samples with SMI values greater than unity were regarded as having a noticeable impact on seawater mixing. The SMI values for the investigated groundwaters did not show a strong correlation with the distance from the coastline or well depth, suggesting that the hydrogeological setting of coastal aquifers in the western coastal regions of South Korea is quite complex.

As public concerns about groundwater contamination by seawater intrusion have been raised, the Korean government has established a seawater intrusion monitoring program. Official monitoring of seawater intrusion first started in 1992 at Jeju Island, and it was expanded to mainland South Korea in 1998 [55]. Starting with 10 monitoring wells in 1998, as of 2019, 190 monitoring wells of the Seawater Intrusion Monitoring Network (SIMN) are located along the coastal area of mainland South Korea. They are operated by the Korea Rural Community Corporation [119].

Using the data obtained from the automatic monitoring of the water level and EC and periodic chemical analysis collected from 55 monitoring wells of the SIMN in 2004, Lee and Song [52] evaluated the groundwater chemistries in the western and southern coastal regions of South Korea to identify the advance of seawater intrusion. The ranges of chemical components of the groundwater were quite large but generally showed a lognormal distribution. Large quantities of groundwater samples were grouped into the $\mathrm{Na}-\mathrm{Cl}$ and $\mathrm{Ca}-\mathrm{Cl}$ types, with the $\mathrm{Na}-\mathrm{Cl}$ type representing the influence of seawater intrusion. High levels of EC extended over $1.6 \mathrm{~km}$ inland and high chloride concentrations reached up to $1.2 \mathrm{~km}$ inland. Further, Lee et al. [55] analyzed monitoring data from 45 monitoring wells of the SIMN by using correlation analysis and trend analyses. Decreases in groundwater levels were mostly associated with groundwater exploitation for irrigation and the accompanied increases in EC values. The locations of the monitoring wells with increasing trends of EC values were scattered somewhat evenly over the coastal areas, indicating that seawater intrusion is occurring widely.

Later, Song and Zemansky [60] evaluated the vulnerability of coastal groundwater systems to sea level rise using groundwater monitoring data collected from ten selected monitoring wells of the SIMN and sea level data from seven adjacent gauging stations. Cross-correlation analysis showed that spatial differences in sea level rise affected the groundwater level, particularly during the dry season. Vertical EC profiles showed that groundwater wells at reclaimed lands were more influenced by sea level variation compared with groundwater systems in the mainland. It was concluded that sea level changes resulting from climate change and rainfall could affect groundwater levels in South Korea.

Park et al. [61] used data from 92 monitoring wells of the SIMN during the period 2007-2009 to evaluate the groundwater geochemistry throughout the eastern, western, and southern coastal regions of South Korea. On the basis of EC values, groundwaters were grouped into fresh (56\%), brackish (7\%), and saline (37\%). The threshold values of bicarbonate, chloride, and bromide were suggested to be suitable proxies for assessing 
the extent of the water-rock interaction and seawater mixing. It was shown that around $41-50 \%$ of the groundwater samples were affected by seawater mixing.

\section{Summary and Future Perspectives}

In this review paper, we overviewed the seawater intrusion studies conducted in the western coastal regions of South Korea over the past 20 years, and summarized the results of individual studies according to the study location, methods used, and major findings. The general methods to identify and interpret seawater intrusion and the accompanying geochemical processes are also discussed.

Among the four provinces in South Korea in contact with the western coastline (i.e., Gyeonggi-do, Chungcheongnam-do, Jeollabuk-do, and Jeollanam-do), studies on Chungcheongnam-do have been relatively limited (Figure 1), although Taean-gun in Chungcheongnam-do was selected as the area most vulnerable to seawater intrusion in the modeling study of Kim and Yang [77]. Other than regional-scale studies, including those using the SIMN $[47,52,55,60,61]$, only one study has been conducted in Chungcheongnamdo, to test a device for detecting the freshwater-seawater interface [78]. Considering that Chungcheongnam-do is close to Daejeon and Sejong, which are highly populated and economically fast-growing cities in South Korea, more research in this province is anticipated in the future.

Previous studies have largely relied on geochemical investigations, along with statistical analysis. Geochemical investigations have involved graphical representation of hydrogeochemistry (e.g., contouring, Piper diagram, and water type classification), comparison with the molar ratios of seawater, and mixing ratio calculations using conservative anions, such as $\mathrm{Cl}^{-}$and $\mathrm{Br}^{-}$. Isotope analysis has also been a useful tool to identify sources of salinization and for the calculation of the freshwater and seawater water mixing ratios. Because there are many different contamination sources in coastal aquifers, statistical analyses, such as factor analysis, PCA, cluster analysis, and correlation analysis, have been used to differentiate multiple contamination sources. Geophysical investigations and numerical modeling have not been as abundant as geochemical investigations. Future research is expected to combine various research tools to acquire a better understanding of the hydrogeological systems in the coastal areas.

Through the investigations of individual studies and regional-scale studies, it has been found that groundwater geochemistry in the western coastal aquifers is largely affected by mixing with seawater, cation exchange processes during seawater intrusion, artificial contamination, water-rock interactions, and redox processes. Therefore, more precise methods to identify and interpret seawater intrusion processes is required. Seawater intrusion is prone to occur because of intensive groundwater exploitation in the coastal areas and sea level rise resulting from climate changes. National-level plans to reduce seawater intrusion and manage water resources in the coastal areas should be established. While climate change may have significant impacts on sea level rise, it is difficult to be controlled by local governments. Within the perspective of preventing seawater intrusion at the local scale, a strategy on limiting the exploitation of groundwater should be carefully implemented.

On the basis of lessons learned from previous studies, future research interests may include, but are not limited to, laboratory (column) experiments to understand the underlying geochemical processes, such as mineral dissolution and precipitation and ion exchange reactions; reactive transport modelling, incorporating cation exchange processes; groundwater flow modeling, including density-dependent flow and transient pumping scenarios; modeling of surface water-groundwater interaction, reflecting climate changes; implications of microbial communities with respect to ecological changes; and impacts of saline water on geological storage sites. In addition, the use of strontium, boron, and lithium isotopes can improve our knowledge of the hydrogeochemical processes [26]. The use of multi-isotope studies can provide complementary information from difference sources, enabling a comprehensive evaluation of natural and anthropogenic processes. 
Pyrosequencing and microbial community analysis can be used to monitor groundwater quality and detect seawater intrusion. Distribution of bacterial species can be different among groundwaters with different salinities [71], and may be dependent on submarine groundwater discharge and tidal stage [72]. This method can be particularly useful in the areas where water chemistry may not be significantly different. Research needs for developing geological storage sites (e.g., underground LPG caverns [42,51,65,70,120], geological repositories for radioactive wastes [76,84], and carbon dioxide capture and storage (CCS) sites [121-123]) may increase in these regions in the future. Because seawater can affect the stability of concrete and steel structures $[76,124]$, careful monitoring of groundwater systems is required to evaluate the potential impact of seawater intrusion on the management of those sites.

Author Contributions: S.-W.J.: investigation, writing—original draft preparation, writing—review and editing; J.K.: investigation, visualization, writing-review and editing; H.J.: investigation, visualization, writing-review and editing; J.L.: investigation, writing—original draft preparation, writing - review and editing. All authors have read and agreed to the published version of the manuscript.

Funding: This research was supported by a National Research Foundation of Korea (NRF) grant funded by the Ministry of Science and ICT (NRF-2019R1A2C1086667) and by research funds of Jeonbuk National University in 2020. This work was partially supported by two research grants, KIMST20190361 from the Korea Ministry of Oceans and Fisheries and the National Research Council of Science \& Technology (NST) grant of the Korea government (MSIP) (CAP-17-05-KIGAM).

Institutional Review Board Statement: Not applicable.

Informed Consent Statement: Not applicable.

Data Availability Statement: Data sharing is not applicable.

Conflicts of Interest: The authors declare no conflict of interest.

\section{References}

1. Andersen, M.S.; Nyvang, V.; Jakobsen, R.; Postma, D. Geochemical processes and solute transport at the seawater/freshwater interface of a sandy aquifer. Geochim. Cosmochim. Acta 2005, 69, 3979-3994. [CrossRef]

2. Werner, A.D.; Bakker, M.; Post, V.E.A.; Vandenbohede, A.; Lu, C.; Ataie-Ashtiani, B.; Simmons, C.T.; Barry, D.A. Seawater intrusion processes, investigation and management: Recent advances and future challenges. Adv. Water Resour. 2013, 51, 3-26. [CrossRef]

3. Nadler, A.; Magaritz, M.; Mazor, E. Chemical reactions of seawater with rocks and freshwater experimental and field observations on brackish waters in Israel. Geochim. Cosmochim. Acta 1981, 44, 879-886. [CrossRef]

4. Magaritz, M.; Luzier, J.E. Water-rock interactions and seawater-freshwater mixing effects in the coastal dune aquifer, Coos Bay, Oregon. Geochim. Cosmochim. Acta 1985, 49, 2515-2525. [CrossRef]

5. Dixon, W.; Chiwell, B. The use of hydrochemical sections to identify recharge areas and saline intrusions in alluvial aquifers, Southeast Queensland, Australia. J. Hydrol. 1992, 135, 259-274. [CrossRef]

6. Morell, I.; Giménez, E.; Esteller, M.V. Application of principal components analysis to the study of salinization on the Castellon Plain (Spain). Sci. Total Environ. 1996, 177, 161-171. [CrossRef]

7. Giménez, E.; Morell, I. Hydrogeochemical analysis of salinization processes in the coastal aquifer of Oropesa (Castellon, Spain). Environ. Geol. 1997, 29, 118-131. [CrossRef]

8. Edet, A.E.; Okereke, C.S. A regional study of saltwater intrusion in southeastern Nigeria based on the analysis of geoelectrical and hydrochemical data. Environ. Geol. 2001, 40, 1278-1289. [CrossRef]

9. Cruz, J.V.; Coutinho, R.; Pacheco, D.; Cymbron, R.; Antunes, P.; Freire, P.; Mendes, S. Groundwater salinization in the Azores archipelago (Portugal). Environ. Earth Sci. 2011, 62, 1273-1285. [CrossRef]

10. Sherif, M.M.; Singh, V.P. Effect of climate change on sea water intrusion in coastal aquifers. Hydrol. Process. 1999, 13, 1277-1287. [CrossRef]

11. Werner, A.D.; Simmons, C.T. Impact of sea-level rise on sea water intrusion in coastal aquifers. Ground Water 2009, 47, 197-204. [CrossRef]

12. Ferguson, G.; Gleeson, T. Vulnerability of coastal aquifers to groundwater use and climate change. Nat. Clim. Chang. 2012, 2, 342-345. [CrossRef]

13. Rasmussen, P.; Sonnenborg, T.O.; Goncear, G.; Hinsby, K. Assessing impacts of climate change, sea level rise, and drainage canals on saltwater intrusion to coastal aquifer. Hydrol. Earth Syst. Sci. 2013, 17, 421-443. [CrossRef] 
14. Vengosh, A.; Rosenthal, E. Saline groundwater in Israel: Its bearing on the water crisis in the country. J. Hydrol. 1994, 156, 389-430. [CrossRef]

15. Ozler, H.M. Hydrochemistry and salt-water intrusion in the Van aquifer, east Turkey. Environ. Geol. 2003, 43, 759-775. [CrossRef]

16. Han, D.M.; Cao, G.L.; McCallum, J.; Song, X.F. Residence times of groundwater and nitrate transport in coastal aquifer systems: Daweijia area, northeastern China. Sci. Total Environ. 2015, 538, 539-554. [CrossRef]

17. Chatton, E.; Aquilina, L.; Petelet-Giraud, E.; Cary, L.; Bertrand, G.; Labasque, T.; Hirata, R.; Martins, V.; Montenegro, S.; Vergnaud, V.; et al. Glacial recharge, salinisation and anthropogenic contamination in the coastal aquifers of Recife (Brazil). Sci. Total Environ. 2016, 569, 1114-1125. [CrossRef]

18. Vallejos, A.; Daniele, L.; Sola, F.; Molina, L.; Pulido-Bosch, A. Anthropic-induced salinization in a dolomite coastal aquifer. Hydrogeochemical processes. J. Geochem. Explor. 2020, 209, 106438. [CrossRef]

19. Yechieli, Y.; Yokochi, R.; Ziberbrand, M.; Lu, Z.T.; Purtschert, R.; Sueltenfuss, J.; Jiang, W.; Zappala, J.; Mueller, P.; Bernier, R.; et al. Recent seawater intrusion into deep aquifer determined by the radioactive noble-gas isotopes ${ }^{81} \mathrm{Kr}$ and ${ }^{39} \mathrm{Ar}$. Earth Planet. Sci. Lett. 2019, 507, 21-29. [CrossRef]

20. Rachid, G.; Alameddine, I.; Najm, M.A.; Qian, S.; El-Fadel, M. Dynamic Bayesian Networks to Assess Anthropogenic and Climatic Drivers of Saltwater Intrusion: A Decision Support Tool Toward Improved Management. Integr. Environ. Assess. Manag. 2021, 17, 202-220. [CrossRef]

21. Mondal, N.C.; Singh, V.P.; Singh, V.S.; Saxena, V.K. Determining the interaction between groundwater and saline water through groundwater major ions chemistry. J. Hydrol. 2010, 388, 100-111. [CrossRef]

22. Alfarrah, N.; Walraevens, K. Groundwater overexploitation and seawater intrusion in coastal areas of arid and semi-arid regions. Water 2018, 10, 143. [CrossRef]

23. Ouhamdouch, S.; Bahir, M.; Ouazar, D. Seawater intrusion into coastal aquifers from semi-arid environments, Case of the alluvial aquifer of Essaouira basin (Morocco). Carbonates Evaporites 2021, 36, 1-12. [CrossRef]

24. Sánchez-Martos, F.; Pulido-Bosch, A.; Molina-Sánchez, L.; Vallejos-Izquierdo, A. Identification of the origin of salinization in groundwater using minor ions (Lower Andarax, Southeast Spain). Sci. Total Environ. 2002, 1-3, 43-58. [CrossRef]

25. Kazakis, N.; Pavlou, A.; Vargemezis, G.; Voudouris, K.S.; Soulios, G.; Pliakas, F.; Tsokas, G. Seawater intrusion mapping using electrical resistivity tomography and hydrochemical data. An application in the coastal area of eastern Thermaikos Gulf, Greece. Sci. Total Environ. 2016, 543, 373-387. [CrossRef]

26. Mahlknecht, J.; Merchán, D.; Rosner, M.; Meixner, A.; Ledesma-Ruiz, R. Assessing seawater intrusion in an arid coastal aquifer under high anthropogenic influence using major constituents, Sr and B isotopes in groundwater. Sci. Total Environ. 2017, 587, 282-295. [CrossRef] [PubMed]

27. Boschetti, T.; González-Hernández, P.; Hernández-Díaz, R.; Naclerio, G.; Celico, F. Seawater intrusion in the Guanahacabibes Peninsula (Pinar del Rio Province, western Cuba): Effects on karst development and water isotope composition. Environ. Earth Sci. 2015, 73, 5703-5719. [CrossRef]

28. Zhang, Q.; Volker, R.E.; Lockington, D.A. Numerical investigation of seawater intrusion at Gooburrum, Bundaberg, Queensland, Australia. Hydrogeol. J. 2004, 12, 674-687. [CrossRef]

29. Werner, A.D.; Laattoe, T. Terrestrial freshwater lenses in stable riverine settings: Occurrence and controlling factors. Water Resour. Res. 2016, 52, 3654-3662. [CrossRef]

30. Costall, A.R.; Harris, B.D.; Teo, B.; Schaa, R.; Wagner, F.M.; Pigois, J.P. Groundwater throughflow and seawater intrusion in high quality coastal aquifers. Sci. Rep. 2020, 10,1-33. [CrossRef]

31. Don, N.C.; Hang, N.T.M.; Araki, H.; Yamanishi, H.; Koga, K. Groundwater resources and management for paddy field irrigation and associated environmental problems in an alluvial coastal lowland plain. Agric. Water Manag. 2006, 84, 295-304. [CrossRef]

32. Yamanaka, M.; Bottrell, S.H.; Wu, J.; Kumagai, Y.; Mori, K.; Satake, H. Chlorine stable isotope evidence for salinization processes of confined groundwater in southwestern Nobi Plain aquifer system, central Japan. J. Hydrol. 2014, 519, 295-306. [CrossRef]

33. Huang, G.; Sun, J.; Zhang, Y.; Chen, Z.; Liu, F. Impact of anthropogenic and natural processes on the evolution of groundwater chemistry in a rapidly urbanized coastal area, South China. Sci. Total Environ. 2013, 463, 209-221. [CrossRef]

34. Han, D.M.; Song, X.F.; Currell, M.J.; Yang, J.L.; Xiao, G.Q. Chemical and isotopic constraints on evolution of groundwater salinization in the coastal plain aquifer of Laizhou Bay, China. J. Hydrol. 2014, 508, 12-27. [CrossRef]

35. Liu, Y.; Jiao, J.J.; Liang, W.; Kuang, X. Hydrogeochemical characteristics in coastal groundwater mixing zone. Appl. Geochem. 2017, 85, 49-60. [CrossRef]

36. Kim, O.-B.; Park, H.-Y. Variation of hydrochemical characteristics of major elements in groundwater by the seawater intrusion in the Byeonsan peninsular, Korea. Geosystem. Eng. 1998, 1, 106-110. [CrossRef]

37. Jeen, S.-W.; Kim, J.-M.; Ko, K.-S.; Yum, B.; Chang, H.-W. Hydrogeochemical characteristics of groundwater in a mid-western coastal aquifer system, Korea. Geosci. J. 2001, 5, 339-348. [CrossRef]

38. Lee, S.-H.; Kim, K.-W.; Ko, I.; Lee, S.-G.; Hwang, H.-S. Geochemical and geophysical monitoring of salinewater intrusion in Korean paddy fields. Environ. Geochem. Health 2002, 24, 277-291. [CrossRef]

39. Kim, J.H.; Kim, R.H.; Lee, J.; Chang, H.W. Hydrogeochemical characterization of major factors affecting the quality of shallow groundwater in the coastal area at Kimje in South Korea. Environ. Geol. 2003, 44, 478-489. [CrossRef]

40. Kim, J.-H.; Yun, B.-W.; Kim, R.-H.; Koh, D.-C.; Cheong, T.-J.; Lee, J.; Chang, H.-W. Application of cluster analysis for the hydrogeochemical factors of saline groundwater in Kimje, Korea. Geosci. J. 2003, 7, 313-322. [CrossRef] 
41. Kim, Y.; Lee, K.-S.; Koh, D.-C.; Lee, D.-H.; Lee, S.-G.; Park, W.-B.; Koh, G.-W.; Woo, N.-C. Hydrogeochemical and isotopic evidence of groundwater salinization in a coastal aquifer: A case study in Jeju volcanic island, Korea. J. Hydrol. 2003, 270, 282-294. [CrossRef]

42. Lee, J.; Kim, R.-H.; Chang, H.-W. Interaction between groundwater quality and hydraulic head in an area around an underground LPG storage cavern, Korea. Environ. Geol. 2003, 43, 901-912. [CrossRef]

43. Hwang, S.; Shin, J.; Park, I.; Lee, S. Assessment of seawater intrusion using geophysical well logging and electrical soundings in a coastal aquifer, Youngkwang-gun, Korea. Explor. Geophys. 2004, 35, 99-104. [CrossRef]

44. Kim, K.; Rajmohan, N.; Kim, H.J.; Hwang, G.-S.; Cho, M.J. Assessment of groundwater chemistry in a coastal region (Kunsan, Korea) having complex contaminant sources: A stoichiometric approach. Environ. Geol. 2004, 46, 763-774. [CrossRef]

45. Kim, J.-H.; Kim, R.-H.; Lee, J.; Cheong, T.-J.; Yum, B.-W.; Chang, H.-W. Multivariate statistical analysis to identify the major factors governing groundwater quality in the coastal area of Kimje, South Korea. Hydrol. Process. 2005, 19, 1261-1276. [CrossRef]

46. Kim, J.H.; Lee, J.; Cheong, T.-J.; Kim, R.-H.; Koh, D.-C.; Ryu, J.-S.; Chang, H.-W. Use of time series analysis for the identification of tidal effect on groundwater in the coastal area of Kimje, Korea. J. Hydrol. 2005, 300, 188-198. [CrossRef]

47. Park, S.-C.; Yun, S.-T.; Chae, K.-T.; Yoo, I.-S.; Shin, K.-S.; Heo, C.-H.; Lee, S.-K. Regional hydrochemical study on salinization of coastal aquifers, western coastal area of South Korea. J. Hydrol. 2005, 313, 182-194. [CrossRef]

48. Kim, R.-H.; Kim, J.-H.; Ryu, J.-S.; Chang, H.-W. Salinization properties of a shallow groundwater in a coastal reclaimed area, Yeonggwang, Korea. Environ. Geol. 2006, 49, 1180-1194. [CrossRef]

49. Kim, K.-Y.; Seong, H.; Kim, T.; Park, K.-H.; Woo, N.-C.; Park, Y.-S.; Koh, G.-W.; Park, W.-B. Tidal effects on variations of fresh-saltwater interface and groundwater flow in a multilayered coastal aquifer on a volcanic island (Jeju Island, Korea). J. Hydrol. 2006, 330, 525-542. [CrossRef]

50. Kim, K.-Y.; Chon, C.-M.; Park, K.-H. A simple method for locating the fresh water-salt water interface using pressure data. Ground Water 2007, 45, 723-728. [CrossRef]

51. Lee, J.; Kim, J.-H.; Kim, H.-M.; Chang, H.-W. Statistical approach to determine the salinized ground water flow path and hydrogeochemical features around the underground LPG cavern, Korea. Hydrol. Process. 2007, 21, 3615-3626. [CrossRef]

52. Lee, J.-Y.; Song, S.-H. Evaluation of groundwater quality in coastal areas: Implications for sustainable agriculture. Environ. Geol. 2007, 52, 1231-1242. [CrossRef]

53. Lee, J.-Y.; Song, S.-H. Groundwater chemistry and ionic ratios in a western coastal aquifer of Buan, Korea: Implication for seawater intrusion. Geosci. J. 2007, 11, 259-270. [CrossRef]

54. Song, S.H.; Lee, J.-Y.; Park, N. Use of vertical electrical soundings to delineate seawater intrusion in a coastal area of Byunsan, Korea. Environ. Geol. 2007, 52, 1207-1219. [CrossRef]

55. Lee, J.-Y.; Yi, M.-J.; Song, S.-H.; Lee, G.-S. Evaluation of seawater intrusion on the groundwater data obtained from the monitoring network in Korea. Water Int. 2008, 33, 127-146. [CrossRef]

56. Kim, K.-Y.; Chon, C.-M.; Park, K.-H.; Park, Y.-S.; Woo, N.-C. Multi-depth monitoring of electrical conductivity and temperature of groundwater at a multilayered coastal aquifer: Jeju Island, Korea. Hydrol. Process. 2008, 22, 3724-3733. [CrossRef]

57. Kim, K.-Y.; Park, Y.-S.; Kim, G.-P.; Pakr, K.-H. Dynamic freshwater-saline water interaction in the coastal zone of Jeju Island, South Korea. Hydrogeol. J. 2009, 17, 617-629. [CrossRef]

58. Chae, K.-T.; Yun, S.-T.; Yun, S.-M.; Kim, K.-H.; So, C.-S. Seawater-freshwater mixing and resulting calcite dissolution: An example from a coastal alluvial aquifer in eastern South Korea. Hydrol. Sci. J. 2012, 57, 1672-1683. [CrossRef]

59. Kim, T.H.; Chung, S.Y.; Park, N.; Hamm, S.-Y.; Lee, S.Y.; Kim, B.-W. Combined analyses of chemometrics and kriging for identifying groundwater contamination sources and origins at the Masan coastal area in Korea. Environ. Earth Sci. 2012, 67, 1373-1388. [CrossRef]

60. Song, S.-H.; Zemansky, G. Vulnerability of groundwater systems with sea level rise in coastal aquifers, South Korea. Environ. Earth Sci. 2012, 65, 1865-1876. [CrossRef]

61. Park, Y.; Lee, J.-Y.; Kim, J.-H.; Song, S.-H. National scale evaluation of groundwater chemistry in Korea coastal aquifers: Evidences of seawater intrusion. Environ. Earth Sci. 2012, 66, 707-718. [CrossRef]

62. Park, H.-Y.; Jang, K.; Ju, J.W.; Yeo, I.W. Hydrogeological characterization of seawater intrusion in tidally-forced coastal fractured bedrock aquifer. J. Hydrol. 2012, 446-447, 77-89. [CrossRef]

63. Jun, K.W.; Jang, C.D. Effects of salinization of groundwater along the western coast of Korea are reduced by artificially recharging with freshwater. J. Coast. Res. 2013, 65, 60-63. [CrossRef]

64. Kim, K.-Y.; Han, W.S.; Park, E. The impact of highly permeable layer on hydraulic system in a coastal aquifer. Hydrol. Process. 2013, 27, 3128-3138. [CrossRef]

65. Lim, J.-W.; Lee, E.; Moon, H.S.; Lee, K.-K. Integrated investigation of seawater intrusion around oil storage caverns in a coastal fractured aquifer using hydrogeochemical and isotopic data. J. Hydrol. 2013, 486, 202-210. [CrossRef]

66. Kim, D.-M.; Yun, S.-T.; Kwon, M.J.; Mayer, B.; Kim, K.-H. Assessing redox zones and seawater intrusion in a coastal aquifer in South Korea using hydrogeological, chemical and isotopic approaches. Chem. Geol. 2014, 390, 119-134. [CrossRef]

67. Lee, B.S.; Song, S.-H.; Kim, J.S.; Um, J.Y.; Nam, K. Availability of coastal groundwater discharge as an alternative water resource in a large-scale reclaimed land, Korea. Environ. Earth Sci. 2014, 71, 1521-1532. [CrossRef]

68. Chung, S.Y.; Venkatramanan, S.; Kim, T.H.; Kim, D.S.; Ramkumar, T. Influence of hydrogeochemical processes and assessment of suitability for groundwater uses in Busan City, Korea. Environ. Dev. Sustain. 2015, 17, 423-441. [CrossRef] 
69. Venkatramanan, S.; Chung, S.Y.; Kim, T.H.; Prasanna, M.V.; Hamm, S.Y. Assessment and distribution of metals contamination in groundwater: A case study of Busan city, Korea. Water Qual. Expo. Health 2015, 7, 219-225. [CrossRef]

70. Lee, E.; Lim, J.-W.; Moon, H.S.; Lee, K.-K. Assessment of seawater intrusion into underground oil storage cavern and prediction of its sustainability. Environ. Earth Sci. 2015, 73, 1179-1190. [CrossRef]

71. Unno, T.; Kim, J.; Kim, Y.; Nguyen, S.G.; Guevarra, R.B.; Kim, G.P.; Lee, J.-H.; Sadowsky, M.J. Influence of seawater intrusion on microbial communities in groundwater. Sci. Total Environ. 2015, 532, 337-343. [CrossRef]

72. Lee, E.; Shin, D.; Hyun, S.P.; Ko, K.-S.; Moon, H.S.; Koh, D.-C.; Ha, K.; Kim, B.-Y. Periodic change in coastal microbial community structure associated with submarine groundwater discharge and tidal fluctuation. Limnol. Oceanogr. 2017, 62, 437-451. [CrossRef]

73. Venkatramanan, S.; Chung, S.Y.; Selvam, S.; Son, J.H.; Kim, Y.J. Interrelationship between geochemical elements of sediment and groundwater at Samrak Park Delta of Nakdong River Basin in Korea: Multivariate statistical analyses and artificial neural network approaches. Environ. Earth Sci. 2017, 76, 456. [CrossRef]

74. Venkatramanan, S.; Chung, S.Y.; Selvam, S.; Lee, S.Y.; Elzain, H.E. Factors controlling groundwater quality in the Yeonjegu District of Busan City, Korea, using the hydrogeochemical processes and fuzzy GIS. Environ. Sci. Pollut. Res. 2017, 24, 23679-23693. [CrossRef]

75. Chung, S.Y.; Senapathi, V.; Sekar, S.; Kim, T.H. Time series analyses of hydrological parameter variations and their correlations at a coastal area in Busan, South Korea. Hydrogeol. J. 2018, 26, 1875-1885. [CrossRef]

76. Kim, Y.-T.; Hyun, S.G.; Cheong, J.-Y.; Woo, N.C.; Lee, S. Hydrogeochemistry in the coastal area during construction of geological repository. J. Hydrol. 2018, 562, 40-49. [CrossRef]

77. Kim, I.H.; Yang, J.-S. Prioritizing countermeasures for reducing seawater-intrusion area by considering regional characteristics using SEAWAT and a multicriteria decision-making method. Hydrol. Process. 2018, 32, 3741-3757. [CrossRef]

78. Kim, Y.; Yoon, H.; Lee, S.-H. Freshwater-salt water interface dynamics during pumping tests. Acque Sotter. Ital. J. Groundw. 2019, 8, 35-39. [CrossRef]

79. Kim, R.-H.; Kim, J.-H.; Ryu, J.-S.; Koh, D.-C. Hydrogeochemical characteristics of groundwater influenced by reclamation, seawater intrusion, and land use in the coastal area of Yeonggwang, Korea. Geosci. J. 2019, 23, 603-619. [CrossRef]

80. Chang, S.W.; Chung, I.-M.; Kim, M.-G.; Tolera, M.; Koh, G.-W. Application of GALDIT in assessing the seawater intrusion vulnerability of Jeju Island, South Korea. Water 2019, 11, 1824. [CrossRef]

81. Chang, S.W.; Chung, I.-M.; Kim, M.-G.; Yifru, B.A. Vulnerability assessment considering impact of future groundwater exploitation on coastal groundwater resources in northeastern Jeju Island, South Korea. Environ. Earth Sci. 2020, 79, 498. [CrossRef]

82. Lee, B.D.; Jeong, C.H.; Lee, Y.C.; Lee, Y.J.; Yang, J.H.; Choo, C.O.; Jang, H.W.; Oh, Y.H.; Hong, J.W. Statistical analysis and thermodynamic equilibrium modelling for chemical composition of groundwater and spring water at Jeju Island, South Korea. Water 2020, 12, 777. [CrossRef]

83. Shin, J.; Hwang, S. A Borehole-based approach for seawater intrusion in heterogeneous coastal aquifers, eastern part of Jeju Island, Korea. Water 2020, 12, 609. [CrossRef]

84. Kwon, E.; Park, J.; Lee, J.M.; Kim, Y.-T.; Woo, N.C. Spatiotemporal changes in hydrogeochemistry of coastal groundwater through the construction of underground disposal facility for low and intermediate level radioactive wastes in Korea. J. Hydrol. 2020, 584, 124750. [CrossRef]

85. Jung, E.; Park, N.; Park, J. Composite modeling for evaluation of groundwater and soil salinization on the multiple reclaimed land due to sea-level rise. Transp. Porous Med. 2020, 136, 271-293. [CrossRef]

86. Kim, G.-B. A study on the establishment of groundwater protection area around a saline waterway by combining artificial neural network and GIS-based AHP. Environ. Earth Sci. 2020, 79, 117. [CrossRef]

87. Shin, K.; Koh, D.-C.; Jung, H.; Lee, J. The hydrogeochemical characteristics of groundwater subjected to seawater intrusion in the archipelago, Korea. Water 2020, 12, 1542. [CrossRef]

88. Ju, Y.; Massoudieh, A.; Green, C.T.; Lee, K.-K.; Kaown, D. Complexity of groundwater age mixing near a seawater intrusion zone based on multiple tracers and Bayesian inference. Sci. Total Environ. 2021, 753, 141994. [CrossRef]

89. Youn, J.-S. High salinity factors of ground-water in eastern part of Cheju Island, Korea. Chejudo Res. 1986, 3, 309-326, (In Korean with English abstract).

90. Lee, S.K.; Cho, J.D.; Koo, S.B. Evaluation of TEM sounding for detection of sea-water contamination. J. Geol. Soc. Korea 1988, 24, 71-81, (In Korean with English abstract).

91. Choi, S.H. Cheju Island formation and groundwater characteristics. Chejudo Res. 1988, 5, 59-77, (In Korean with English abstract).

92. Choi, S.-H.; Kim, Y.-K. Geochemical characteristics of groundwater in Cheju Island. J. Geol. Soc. Korea 1989, 25, 230-238, (In Korean with English abstract).

93. Choi, S.H.; Kim, Y.K.; Lee, D.Y. Sea water intrusion in the coastal area of Cheju Volcanic Island, Korea. J. Kor. Inst. Mining Geol. 1991, 24, 319-327.

94. Lee, K. On the hydrodynamic balance of fresh and salt waters in the Cheju Island. J. Geol. Soc. Korea 1992, 28, 649-664.

95. Lee, S.-B.; Kim, K.-Y.; Han, S.-R.; Hahn, J.-S. The study on the increased causes of chloride $\left(\mathrm{Cl}^{-}\right)$concentration of the Samyan 3rd pumping station in Cheju Island. J. Korean Soc. Groundw. Environ. 1997, 4, 85-94, (In Korean with English abstract).

96. Park, N.-S.; Lee, Y.-D. Seawater intrusion due to ground water developments in eastern and central Cheju watersheds. J. Korean Soc. Groundw. Environ. 1997, 4, 5-13, (In Korean with English abstract). 
97. Booh, S.A.; Jeong, G.C. Saline water intrusion into fresh groundwater aquifer of eastern area, the Cheju Island. J. Eng. Geol. 2000, 10, 115-130, (In Korean with English abstract).

98. Himi, M.; Tapias, J.; Benabdelouahab, S.; Salhi, A.; Rivero, L.; Elgettafi, M.; El Mandour, A.; Stitou, J.; Casas, A. Geophysical characterization of saltwater intrusion in a coastal aquifer: The case of Martil-Alila plain (North Morocco). J. Afr. Earth Sci. 2017, 126, 136-147. [CrossRef]

99. Lee, J.; Ko, K.-S.; Kim, J.-M.; Chang, H.-W. Multivariate statistical analysis of underground gas storage caverns on groundwater chemistry in Korea. Hydrol. Process. 2008, 22, 3410-3417. [CrossRef]

100. Ko, K.-S.; Lee, J.; Lee, K.-K.; Chang, H.-W. Multivariate statistical analysis for groundwater mixing ratios around underground storage caverns in Korea. Carbonates Evaporites 2010, 25, 35-42. [CrossRef]

101. Kim, J.-M.; Lee, J. Time series analysis for evaluating hydrological responses of pore-water pressure to rainfall in a slope. Hydrol. Sci. J. 2017, 62, 1412-1421. [CrossRef]

102. Laaksoharju, M.; Skårman, C.; Skårman, E. Multivariate mixing and mass balance (M3) calculations, a new tool for decoding hydrogeochemical information. Appl. Geochem. 1999, 14, 861-871. [CrossRef]

103. Stetzenbach, K.J.; Farnham, I.M.; Hodge, V.F.; Johannesson, K.H. Using multivariate statistical analysis of groundwater major cation and trace element concentrations to evaluate groundwater flow in a regional aquifer. Hydrol. Process. 1999, 13, 2655-2673. [CrossRef]

104. De Filippis, G.; Foglia, L.; Giudici, M.; Mehl, S.; Margiotta, S.; Negri, S.L. Seawater intrusion in karstic, coastal aquifers: Current challenges and future scenarios in the Taranto area (southern Italy). Sci. Total Environ. 2016, 573, 1340-1351. [CrossRef]

105. Paniconi, C.; Khlaifi, I.; Lecca, G.; Giacomelli, A.; Tarhouni, J. Modeling and analysis of seawater intrusion in the coastal aquifer of Cap-Bon, Tunisia. Transp. Porous Med. 2001, 43, 3-28. [CrossRef]

106. Mercer, J.W.; Larson, S.P.; Faust, C.R. Simulation of salt-water interface motion. Ground Water 1980, 18, 374-385. [CrossRef]

107. Kim, C.-S.; Kim, K.-S.; Bae, D.-S.; Song, S.-H. Hydrogeological characteristics of seawater intrusion in the coastal area. J. Korean Soc. Groundw. Environ. 1997, 4, 61-72, (In Korean with English abstract).

108. Shin, I.-H.; Park, C.-Y.; Ahan, K.-S.; Jeong, Y.-J. Hydrogeochemistry of groundwaters at the Gogum island area in Jeonnam, Korea. JKEES 2002, 23, 474-485, (In Korean with English abstract).

109. Pulido-Leboeuf, P. Seawater intrusion and associated processes in a small coastal complex aquifer (Castell de Ferro, Spain). Appl. Geochem. 2004, 19, 1517-1527. [CrossRef]

110. Na, C.-K.; Son, C.-I. Groundwater quality and pollution characteristics at Seomjin River Basin: Pollution source and risk assessment. Econ. Environ. Geol. 2005, 38, 261-272, (In Korean with English abstract).

111. Capaccioni, B.; Didero, M.; Paletta, C.; Didero, L. Saline intrusion and refreshening in a multilayer coastal aquifer in the Catania Plain (Sicily, Southern Italy): Dynamics of degradation processes according to the hydrochemical characteristics of groundwaters. J. Hydrol. 2005, 307, 1-16. [CrossRef]

112. Faye, S.; Maloszewki, P.; Stichler, W.; Trimborn, P.; Faye, S.C.; Gaye, C.B. Groundwater salinization in the Saloum (Senegal) delta aquifer: Minor elements and isotopic indicators. Sci. Total Environ. 2005, 343, 243-259. [CrossRef] [PubMed]

113. Kim, H.-J.; Hamm, S.-Y.; Kim, N.-H.; Cheong, J.-Y.; Lee, J.-H.; Jang, S. Characteristics of groundwater contamination caused by seawater intrusion and agricultural activity in Sacheon and Hadong areas, Republic of Korea. Econ. Environ. Geol. 2009, 42, 575-589, (In Korean with English abstract).

114. Han, D.; Post, V.E.A.; Song, X. Groundwater salinization processes and reversibility of seawater intrusion in coastal carbonate aquifers. J. Hydrol. 2015, 531, 1067-1080. [CrossRef]

115. Argamasilla, M.; Baberá, J.A.; Andreo, B. Factors controlling groundwater salinization and hydrogeochemical processes in coastal aquifers from southern Spain. Sci. Total Environ. 2017, 580, 50-68. [CrossRef] [PubMed]

116. Hamm, S.-Y.; Cheong, J.-Y.; Jang, S.; Jung, C.-Y.; Kim, B.-S. Relationship between transmissivity and specific capacity in the volcanic aquifers of Jeju Island, Korea. J. Hydrol. 2005, 310, 111-121. [CrossRef]

117. Davis, G.H.; Lee, C.K.; Bradley, E.; Payne, B.R. Geohydrologic interpretations of a volcanic island from environmental isotopes. Water Resour. Res. 1970, 6, 99-109. [CrossRef]

118. Maloszewski, P.; Zuber, A. Determining the turnover time of groundwater systems with the aid of environmental tracers: 1. Models and their applicability. J. Hydrol. 1982, 57, 207-231. [CrossRef]

119. Ministry of Agriculture, Food and Rural Affairs; Korea Rural Community Corporation. Annual Report on the Seawater Intrusion Monitoring Network in Korea (2019); 11-1543000-001105-10; Korea Rural Community Corporation: Naju, Korea, 2019. (In Korean)

120. Lee, J.-Y.; Lim, H.S. Identification and characterization of the encrusting materials in a coastal liquefied petroleum gas storage cavern. Environ. Earth Sci. 2010, 61, 1165-1177. [CrossRef]

121. Kwon, Y.K.; Chang, C.; Shinn, Y. Security and safety assessment of the small-scale offshore $\mathrm{CO}_{2}$ storage demonstration project in the Pohang Basin. J. Eng. Geol. 2018, 28, 217-246, (In Korean with English abstract). [CrossRef]

122. KIGAM. Evaluation of Large-Scale $\mathrm{CO}_{2}$ Geological Storage Potential; GP2017-027-2019; KIGAM: Daejeon, Korea, 2019. (In Korean)

123. Kim, K.-H.; Yun, S.-T.; Yu, S.; Choi, B.-Y.; Kim, M.-J.; Lee, K.-J. Geochemical pattern recognitions of deep thermal groundwater in South Korea using self-organizing map: Identified pathways of geochemical reaction and mixing. J. Hydrol. 2020, $589,125202$. [CrossRef]

124. Luo, C.-Y.; Shen, S.-L.; Han, J.; Ye, G.-L.; Horpibulsuk, S. Hydrogeochemical environment of aquifer groundwater in Shanghai and potential hazards to underground infrastructures. Nat. Hazards 2015, 78, 753-774. [CrossRef] 